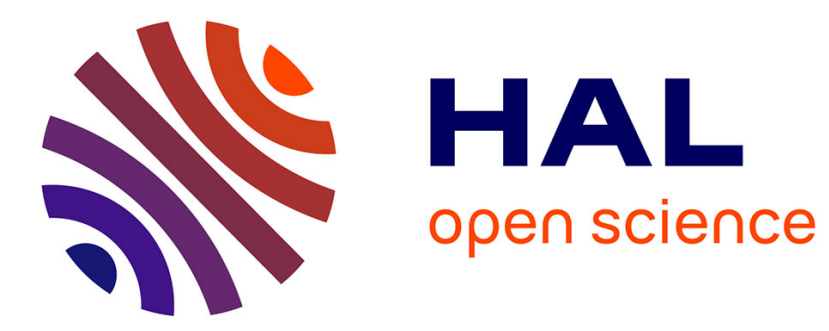

\title{
Speciation of [Cp*2M2O5] in Polar and Donor Solvents
}

Pelin Sözen-Aktaş, Iker Del rosal, Eric Manoury, Funda Demirhan, Agustí

Lledós, Rinaldo Poli

\section{To cite this version:}

Pelin Sözen-Aktaş, Iker Del rosal, Eric Manoury, Funda Demirhan, Agustí Lledós, et al.. Speciation of [Cp*2M2O5] in Polar and Donor Solvents. Chemistry - A European Journal, 2013, 19 (12), pp.39693985. 10.1002/chem.201203075 . hal-02908715

\section{HAL Id: hal-02908715 https://hal.science/hal-02908715}

Submitted on 29 Jul 2021

HAL is a multi-disciplinary open access archive for the deposit and dissemination of scientific research documents, whether they are published or not. The documents may come from teaching and research institutions in France or abroad, or from public or private research centers.
L'archive ouverte pluridisciplinaire HAL, est destinée au dépôt et à la diffusion de documents scientifiques de niveau recherche, publiés ou non, émanant des établissements d'enseignement et de recherche français ou étrangers, des laboratoires publics ou privés. 


\title{
Speciation of $\left[\mathrm{Cp}_{2}{ }_{2} \mathrm{M}_{2} \mathrm{O}_{5}\right](\mathrm{M}=\mathrm{Mo}, \mathrm{W})$ in polar and donor solvents
}

\author{
Pelin Sözen-Aktaş, ${ }^{[a, b, c]}$ Iker Del Rosal, ${ }^{[\mathrm{d}]}$ Eric Manoury, ${ }^{[\mathrm{a}, \mathrm{b}]}$ Funda Demirhan, ${ }^{[\mathrm{c}]}$ Agustí Lledós, ${ }^{*[\mathrm{~d}]}$ \\ and Rinaldo Poli*[a,b,e]
}

\begin{abstract}
The speciation of compounds $\left[\mathrm{Cp}_{2}{ }_{2} \mathrm{M}_{2} \mathrm{O}_{5}\right](\mathrm{M}=\mathrm{Mo}, \mathrm{W})$ in different protic and aprotic polar solvents (methanol, dimethyl sulfoxide, acetone, acetonitrile), in the presence of variable amounts of water or acid/base, has been investigated by ${ }^{1} \mathrm{H}$ NMR spectrometry and electrical conductivity. Specific hypotheses suggested by the experimental results have been further probed by DFT calculations. The solvent (S) assisted ionic dissociation to generate $\left[\mathrm{Cp} * \mathrm{MO}_{2}(\mathrm{~S})\right]^{+}$and $\left[\mathrm{Cp} * \mathrm{MO}_{3}\right]^{-}$takes place extensively for both metals only in water-methanol mixtures. Equilibrium amounts of the neutral hydroxido species $\left[\mathrm{Cp} * \mathrm{MO}_{2}(\mathrm{OH})\right]$ are generated in the presence of water, the relative amount increasing in the order $\mathrm{MeCN} \approx$ acetone $<\mathrm{MeOH}<$ DMSO. Addition of a base $\left(\mathrm{Et}_{3} \mathrm{~N}\right)$ converts

$\left[\mathrm{Cp}_{2}{ }_{2} \mathrm{M}_{2} \mathrm{O}_{5}\right]$ into $\mathrm{Et}_{3} \mathrm{NH}^{+}\left[\mathrm{Cp}^{*} \mathrm{MO}_{3}\right]^{-}$, for which the presence of a $\mathrm{N}-\mathrm{H} \cdots \mathrm{O}=\mathrm{M}$ interaction is revealed by ${ }^{1} \mathrm{H}$ NMR in comparison with the sodium salts, $\mathrm{Na}^{+}\left[\mathrm{Cp} * \mathrm{MO}_{3}\right]^{-}$. These are fully dissociated in DMSO and $\mathrm{MeOH}$, but display a slow equilibrium between free ions and the ion pair in $\mathrm{MeCN}$ and acetone. Only one resonance is observed for mixtures of $\left[\mathrm{Cp}^{*} \mathrm{MO}_{3}\right]^{-}$ and $\left[\mathrm{Cp}^{*} \mathrm{MO}_{2}(\mathrm{OH})\right]$ because of a rapid self-exchange. In the presence of extensive ionic dissociation, only one resonance is observed for mixtures of the cationic $\left[\mathrm{Cp}^{*} \mathrm{MO}_{2}(\mathrm{~S})\right]^{+}$product and the residual undissociated $\left[\mathrm{Cp}^{*}{ }_{2} \mathrm{M}_{2} \mathrm{O}_{5}\right]$ because of a rapid associative exchange via the trinuclear $\left[\mathrm{Cp}_{3}{ }_{3} \mathrm{M}_{3} \mathrm{O}_{7}\right]^{+}$ intermediate. In neat methanol, complex $\left[\mathrm{Cp}_{2}{ }_{2} \mathrm{~W}_{2} \mathrm{O}_{5}\right]$ reacts to yield extensive amounts of a new species, formulated as the monuclear methoxido
\end{abstract}

complex $\left[\mathrm{Cp} * \mathrm{WO}_{2}(\mathrm{OMe})\right]$ on the basis of the DFT study. An equivalent product is not observed for the Mo system. Addition of increasing amounts of water results in the rapid fall off of this product in favor of $\left[\mathrm{Cp}_{2}{ }_{2} \mathrm{~W}_{2} \mathrm{O}_{5}\right]$ and $\left[\mathrm{Cp}^{*} \mathrm{WO}_{2}(\mathrm{OH})\right]$.

Keywords: Molybdenum $\bullet$
Tungsten $\bullet$ Speciation studies $\bullet$
Pentamethylcyclopentadienyl $\bullet$
Aqueous organometallic chemistry
- DFT calculations

\section{Introduction}

Organometallic compounds in high oxidation states, mostly supported by oxido ligands, have emerged as high performance materials for oxidation catalysis. ${ }^{[1]}$ Half-sandwich $\mathrm{Mo}^{\mathrm{VI}}$ complexes, in particular, have recently shown impressive activities as catalysts for olefin epoxidation. ${ }^{[2]} \mathrm{We}$ have been interested in the solution behavior and reactivity of the archetypical pentamethylcyclopentadienylmolybdenum(VI) derivative, $\left[\mathrm{Cp}_{2}{ }_{2} \mathrm{Mo}_{2} \mathrm{O}_{5}\right],{ }^{[3]}$ and have also reported its catalytic activity in cyclooctene epoxidation under a variety of conditions. ${ }^{[4]}$

Recently, we have shown that the tungsten analogue, $\left[\mathrm{Cp}_{2}{ }_{2} \mathrm{~W}_{2} \mathrm{O}_{5}\right]$, now accessible by an improved and simplified synthetic procedure, ${ }^{[3 f]}$ outperforms the molybdenum analogue as an epoxidation catalyst when using $\mathrm{H}_{2} \mathrm{O}_{2}$ as oxidant in $\mathrm{MeCN} .^{[4 b]}$ This observation has interrogated us not only about the detailed catalytic mechanism, but also in terms of the behavior of the catalyst in solution, particularly in $\mathrm{MeCN}$. Previous investigations of $\left[\mathrm{Cp}_{2} \mathrm{Mo}_{2} \mathrm{O}_{5}\right]$ have shown that this compound maintains its neutral dinuclear structure not only in the solid state, but also in solution of organic solvents including methanol, as shown by electrical conductivity studies. ${ }^{[3 a]}$ In a water-rich environment $\left(4: 1 \mathrm{H}_{2} \mathrm{O}\right.$ -

Supporting information for this article is available on the WWW under http://www.chemeurj.org/ or from the author. 
$\mathrm{MeOH}$ mixture; the compound is insoluble in pure $\mathrm{H}_{2} \mathrm{O}$ ), on the other hand, the compound extensively dissociates to yield $\left[\mathrm{Cp} * \mathrm{MoO}_{3}\right]^{-}$and $\left[\mathrm{Cp} * \mathrm{MoO}_{2}\left(\mathrm{H}_{2} \mathrm{O}\right)\right]^{+}$, in equilibrium with a minor amount of the neutral mononuclear hydroxido derivative, $\left[\mathrm{Cp} * \mathrm{MoO}_{2}(\mathrm{OH})\right]{ }^{[3 a]}$ The speciation of this system was completely defined in the full $\mathrm{pH}$ range in a $4: 1 \mathrm{H}_{2} \mathrm{O}-\mathrm{MeOH}$ solution, demonstrating that the anionic form, $\left[\mathrm{Cp}^{*} \mathrm{MoO}_{3}\right]^{-}$, is the dominant species at high $\mathrm{pH}(>\mathrm{ca} .6)$ and the cationic one, $\left[\mathrm{Cp} * \mathrm{MoO}_{2}\left(\mathrm{H}_{2} \mathrm{O}\right)\right]^{+}$ prevails at low $\mathrm{pH}(<\mathrm{ca} .2)$. Dissolution of $\left[\mathrm{Cp}_{2}{ }_{2} \mathrm{Mo}_{2} \mathrm{O}_{5}\right]$ yields acidic solutions ( $\mathrm{pH}$ ca. 4.5) because of acid-base equilibria, which transform a fraction of the cation into the anion with the release of protons. A subsequent more detailed investigation, coupled with a computational study, revealed that rapid equilibrium between the cationic form and the unsolvated $\left[\mathrm{Cp} * \mathrm{MoO}_{2}\right]^{+}$is responsible for the fact that the effective first acid dissociation of $\left[\mathrm{Cp} * \mathrm{MoO}_{2}\left(\mathrm{H}_{2} \mathrm{O}\right)\right]^{+}$ $\left(\mathrm{pKa}_{1}=4.19\right)$ is weaker than the second one $\left(\mathrm{pKa}_{2}=3.65\right) \cdot{ }^{[5]}$

We now report the investigation of the speciation behavior of the related tungsten compound, $\left[\mathrm{Cp}^{*}{ }_{2} \mathrm{~W}_{2} \mathrm{O}_{5}\right]$ and additional information on the behavior of the molybdenum analogue, through a combined ${ }^{1} \mathrm{H}$ NMR and electrical conductivity investigation in a variety of coordinating and dissociating protic and aprotic solvents. Specific aspects of the investigation have been corroborated by a computational study. The tungsten compound is less colored than the molybdenum analogue and thus cannot be conveniently investigated by UV-visible spectroscopy, combined with stoppedflow kinetics, which was the method used to investigate the speciation of $\left[\mathrm{Cp}_{2}{ }_{2} \mathrm{Mo}_{2} \mathrm{O}_{5}\right]{ }^{[3 \mathrm{a}]}$ Nevertheless, the study provides useful information on the distribution of various species derived from $\left[\mathrm{Cp}_{2}{ }_{2} \mathrm{~W}_{2} \mathrm{O}_{5}\right]$ under different conditions in a variety of solvents, which serves as useful reference for the catalytic applications.

\section{Results and Discussion}

\section{Electrical conductivity studies}

As previously shown, compound $\left[\mathrm{Cp}_{2}{ }_{2} \mathrm{Mo}_{2} \mathrm{O}_{5}\right]$ is able to self dissociate in polar solvents according to equation $1 .^{[3 a]}$ The equilibrium is extensively shifted to the right hand side in a $4: 1$ $\mathrm{H}_{2} \mathrm{O} / \mathrm{MeOH}$ solution and to the left hand side in other solvents including pure methanol, the gradual addition of water to a methanol solution causing an increased dissociation as gauged by electrical conductivity measurements. We have therefore started our investigation with corresponding measurement for the $\left[\mathrm{Cp}^{2}{ }_{2} \mathrm{~W}_{2} \mathrm{O}_{5}\right]$ compound in a variety of dissociating and coordinating solvents (acetone, DMSO, methanol and acetonitrile, as well as in a 1:4 $\mathrm{MeOH}-\mathrm{H}_{2} \mathrm{O}$ mixture). The results are shown in Table 1 and compared with those of the related $\left[\mathrm{Cp}_{2}{ }_{2} \mathrm{Mo}_{2} \mathrm{O}_{5}\right]$. The sodium salt $\mathrm{Na}\left[\mathrm{Cp} * \mathrm{WO}_{3}\right]$ has also been studied in order to provide a useful reference and the results are equally shown in Table 1.

$$
\begin{aligned}
& {\left[\mathrm{Cp}_{2} \mathrm{M}_{2} \mathrm{O}_{5}\right]+\text { Solv } \rightleftarrows\left[\mathrm{Cp}^{*} \mathrm{MO}_{2}(\text { Solv })\right]^{+}+\left[\mathrm{Cp}^{*} \mathrm{MO}_{3}\right]^{-}} \\
& (\mathrm{M}=\mathrm{Mo}, \mathrm{W})
\end{aligned}
$$

A first relevant observation is that the conductivity of $\left[\mathrm{Cp}_{2} \mathrm{~W}_{2} \mathrm{O}_{5}\right]$ is relatively similar, though systematically a bit greater, than that of $\left[\mathrm{Cp}_{2}{ }_{2} \mathrm{Mo}_{2} \mathrm{O}_{5}\right]$ in all organic solvents. This indicates a greater dissociation constant for equilibrium 1 for the $\mathrm{W}$ compound, namely a greater tendency to behave as a weak electrolyte. The conductivity value in $\mathrm{MeOH}-\mathrm{H}_{2} \mathrm{O}$, on the other hand, is much greater for the dinuclear $\mathrm{W}$ compound. Before further commenting on this value, it is interesting to compare the conductivity values of
$\left[\mathrm{Cp}{ }_{2} \mathrm{~W}_{2} \mathrm{O}_{5}\right]$ with those of $\mathrm{Na}\left[\mathrm{Cp} * \mathrm{WO}_{3}\right]$, for which an ionic formulation is unambiguous.

The molar conductivity of the sodium salt in DMSO and in $\mathrm{MeOH}$ is within the range typically observed for 1:1 salts, while the values in acetone and acetonitrile are smaller. This could be the result of the sparing solubility of the compound in the two latter solvents (transparent solutions could not be obtained even at the low $4 \cdot 10^{-4} \mathrm{M}$ concentration). However, another reason for these low values is extensive ion pairing, which is confirmed by the NMR study (vide infra). Compound $\mathrm{Na}\left[\mathrm{Cp} * \mathrm{WO}_{3}\right]$ is probably $100 \%$ in the form of solvated ions in the $\mathrm{MeOH}-\mathrm{H}_{2} \mathrm{O}$ mixture, where the measured molar conductivity is again rather high, but not as high as that of $\left[\mathrm{Cp}^{*} \mathrm{~W}_{2} \mathrm{O}_{5}\right]$. Even assuming that the dissociation of $\left[\mathrm{Cp}^{*} \mathrm{~W}_{2} \mathrm{O}_{5}\right]$ according to equilibrium 1 is total, it seems unreasonable to imagine that the greater mobility value of the dinuclear compound results from a greater mobility of the $\left[\mathrm{Cp} * \mathrm{WO}_{2}\left(\mathrm{H}_{2} \mathrm{O}\right)\right]^{+}$ion relative to $\mathrm{Na}^{+}$. Large organic cations are known to have decreased mobility when the size of the organic substituents is greater (for instance, 44.42 for $\mathrm{Me}_{4} \mathrm{~N}^{+}, 23.22$ for $\mathrm{Pr}_{4} \mathrm{~N}^{+}$and 19.31 for $\mathrm{Bu}_{4} \mathrm{~N}^{+}$, vs. 50.20 for $\mathrm{Na}^{+}$in pure $\mathrm{H}_{2} \mathrm{O}$ at $\left.25^{\circ} \mathrm{C}\right) .^{[6]}$

$$
\begin{aligned}
{\left[\mathrm{Cp}^{*} \mathrm{MO}_{2}\left(\mathrm{H}_{2} \mathrm{O}\right)\right]^{+}+\mathrm{H}_{2} \mathrm{O} \rightleftarrows\left[\mathrm{Cp}^{*} \mathrm{MO}_{2}(\mathrm{OH})\right]+\mathrm{H}_{3} \mathrm{O}^{+} } \\
{\left[\mathrm{Cp} * \mathrm{MO}_{2}(\mathrm{OH})\right]+\mathrm{H}_{2} \mathrm{O} \underset{(\mathrm{M}=\mathrm{Mo}, \mathrm{W})}{\rightleftarrows}\left[\mathrm{Cp}^{*} \mathrm{MO}_{3}\right]^{-}+\mathrm{H}_{3} \mathrm{O}^{+} }
\end{aligned}
$$

Table 1. Molar conductivities for $4 \cdot 10^{-4} \mathrm{M}$ solutions of $\left[\mathrm{Cp}^{*}{ }_{2} \mathrm{M}_{2} \mathrm{O}_{5}\right](\mathrm{M}=\mathrm{Mo}$, W $)$ and $\left[\mathrm{Cp} * \mathrm{WO}_{3}^{-}\right] \mathrm{Na}^{+}$in different solvents (in $\mathrm{ohm}^{-1} \cdot \mathrm{cm}^{2} \cdot \mathrm{mole}^{-1}$ )

\begin{tabular}{lllll}
\hline Solvent & {$\left[\mathrm{Cp}^{*} \mathrm{Mo}_{2} \mathrm{O}_{5}\right]$} & {$\left[\mathrm{Cp}_{2}{ }_{2} \mathrm{~W}_{2} \mathrm{O}_{5}\right]$} & $\mathrm{Na}^{+}\left[\mathrm{Cp} * \mathrm{WO}_{3}\right]^{-}$ & $1: 1$ salts \\
\hline Acetone & $0.8^{[\mathrm{a}]}$ & 1.3 & $5.5^{[\mathrm{c}]}$ & $100-140^{[\mathrm{c}]}$ \\
DMSO & 0.5 & 2.3 & 22.1 & $24-44^{[\mathrm{d}]}$ \\
Acetonitrile & $0^{[\mathrm{a}]}$ & 2.6 & $11.5^{[\mathrm{b}]}$ & $120-160^{[\mathrm{c}]}$ \\
Methanol & $4.2^{[\mathrm{a}]}$ & 4.9 & 117.4 & $80-115^{[\mathrm{c}]}$ \\
Methanol- & $102^{[\mathrm{a}]}$ & 313.7 & 214.8 & \\
Water $(20: 80)$ & & & & \\
\hline
\end{tabular}

[a] Values from ref. ${ }^{[3 a]}$. [b] Not totally dissolved. [c] Range of reference values reported for $10^{-3} \mathrm{M}$ solutions. ${ }^{[7]}$ [d] Range of values extrapolated at infinite dilution for a series of alkali metal and tetraalkylammonium salts. ${ }^{\left[{ }^{[8}\right.}$

A reasonable hypothesis to account for this exceptionally high conductivity is the production of protons (for which the mobility in pure water is around $350 \mathrm{ohm}{ }^{-1} \cdot \mathrm{cm}^{2} \cdot \mathrm{mole}^{-1}$ ). Namely, following the self-dissociation of equilibrium 1 , hydrolysis may take place more or less extensively in the presence of water with production of protons according to equations 2 and 3. This phenomenon was indeed demonstrated for the Mo compound, for which accurate measurements yielded the second acid dissociation (equilibrium 3) $\mathrm{pK}_{\mathrm{a}}$ value of $3.65 \pm 0.02^{[3 \mathrm{a}]}$ and the effective first acid dissociation (equilibrium 2) $\mathrm{pK}_{\mathrm{a}}$ value of $4.19 .{ }^{[5]}$ Since the Lewis acidity of Mo and $\mathrm{W}$ is quite similar, leading to comparable expected acidities (for instance, the first and second $\mathrm{pK}_{\mathrm{a}}$ values of $\mathrm{H}_{2} \mathrm{MO}_{4}$ have been estimated in the 3.5-4 and 3.6-4.7 ranges for Mo and in the 3.5-4.1 and 4.0-4.6 ranges for $\mathrm{W}$, respectively), ${ }^{[9]}$ dissolution of $\left[\mathrm{Cp}_{2} \mathrm{~W}_{2} \mathrm{O}_{5}\right]$ in neutral water can also be predicted to generate a fair amount of protons. Indeed, after dissolution of $\left[\mathrm{Cp}_{2}{ }_{2} \mathrm{~W}_{2} \mathrm{O}_{5}\right]$ at a concentration of $4 \cdot 10^{-4} \mathrm{M}$, the $\mathrm{MeOH}-\mathrm{H}_{2} \mathrm{O}$ solution exhibited a $\mathrm{pH}$ value around 4.00. Hence, the much greater value observed for the conductivity of $\left[\mathrm{Cp}_{2}{ }_{2} \mathrm{~W}_{2} \mathrm{O}_{5}\right]$ relative to $\left[\mathrm{Cp}_{2}{ }_{2} \mathrm{Mo}_{2} \mathrm{O}_{5}\right]$ can be attributed to either a more extensive dissociation of the $\mathrm{W}$ dinuclear 
compound, or to a more extensive acid dissociation of the $\left[\mathrm{Cp} * \mathrm{WO}_{2}\left(\mathrm{H}_{2} \mathrm{O}\right)\right]^{+}$ion (lower $\mathrm{pK}_{\mathrm{a}}$ ), or to a combination of both effects.

\section{2. ${ }^{1}$ H NMR studies}

We first present the ${ }^{1} \mathrm{H}$ NMR investigation of $\left[\mathrm{Cp}^{*}{ }_{2} \mathrm{Mo}_{2} \mathrm{O}_{5}\right]$ and $\left[\mathrm{Cp}_{2}{ }_{2} \mathrm{~W}_{2} \mathrm{O}_{5}\right]$ in $\mathrm{D}_{2} \mathrm{O} / \mathrm{CD}_{3} \mathrm{OD}$ (4:1), namely conditions closely related to those of the conductivity study. Subsequently, we shall present the results of the studies in organic solvents, starting with $\mathrm{CD}_{3} \mathrm{OD}$, then DMSO- $d_{6}$, acetone- $d_{6}$ and $\mathrm{CD}_{3} \mathrm{CN}$, in the order that appears to us most suitable for a clearer understanding of this complex system. The spectra of $\mathrm{Na}^{+}\left[\mathrm{Cp}^{*} \mathrm{WO}_{3}\right]^{-}$will also be shown for comparison. Note that the literature reports only the ${ }^{1} \mathrm{H}$ NMR properties of the $\left[\mathrm{Cp}^{*}{ }_{2} \mathrm{M}_{2} \mathrm{O}_{5}\right](\mathrm{M}=\mathrm{Mo}, \mathrm{W})$ compounds in $\mathrm{CDCl}_{3}$ or $\mathrm{CD}_{2} \mathrm{Cl}_{2}$, where only a single resonance was observed (Mo: $\delta 2.01$, 1.99; W: $\delta 2.16,2.13$ in $\mathrm{CDCl}_{3}$ and $\mathrm{CD}_{2} \mathrm{Cl}_{2}$, respectively). ${ }^{[10]}$

\section{(a) Investigations of the $\mathrm{Cp}^{*} \mathrm{M}^{\mathrm{VI}}$ systems $(\mathrm{M}=\mathrm{Mo}, \mathrm{W})$ in $\mathrm{D}_{2} \mathrm{O} / \mathrm{CD}_{3} \mathrm{OD}(4: 1)$.}

The spectrum of a solution of $\left[\mathrm{Cp}_{2} \mathrm{Mo}_{2} \mathrm{O}_{5}\right]$ without any additive exhibits two peaks, a weaker one at $\delta 2.077$ and a stronger one at $\delta$ 1.961 (relative ratio: 30:70), see Figure $1(\operatorname{spectrum} c$ ). Addition of a strong acid $\left(\mathrm{CF}_{3} \mathrm{COOH}\right.$, TFA) to this solution results in an intensity increase for the smaller, lower field resonance, whereas the stronger resonance shifts to $\delta 2.091$ and decreases in intensity (spectrum $b$, relative intensity 65:35). Further addition of excess TFA did not have any effect on the resonances (same positions and relative intensities, spectrum $a$ ). In the latter solution, an estimated residual acid concentration of ca. $8.2 \cdot 10^{-3} \mathrm{M}$ should yield a $\mathrm{pH}$ around 2 . Addition of base $\left(\mathrm{NEt}_{3}\right)$, on the other hand, resulted in disappearance of the $\delta 2.077$ resonance and a shift of the major resonance to $\delta 1.942$ (spectrum $d$ ). Further addition of excess $\mathrm{NEt}_{3}$ had no effect (spectrum $e$ ).

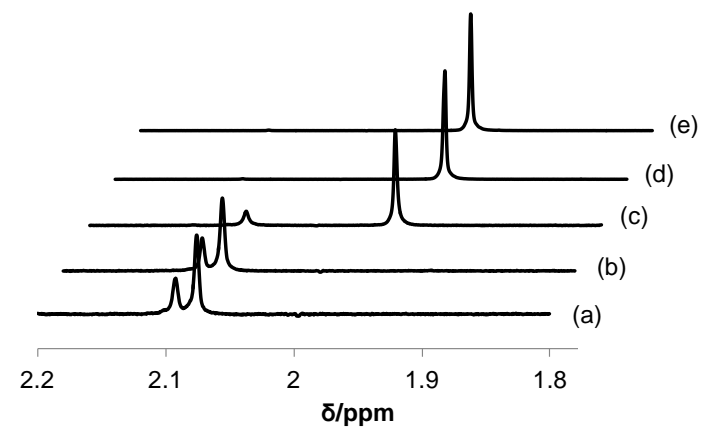

Figure 1. ${ }^{1} \mathrm{H}$ NMR spectra of the $\mathrm{Cp}^{*} \mathrm{Mo}^{\mathrm{VI}}$ system in $\mathrm{D}_{2} \mathrm{O} / \mathrm{CD}_{3} \mathrm{OD}$ (4:1). Compound [Cp $\left.{ }_{2} \mathrm{Mo}_{2} \mathrm{O}_{5}\right]\left(0.5 \mathrm{mg}, 1.8 \cdot 10^{-3} \mathrm{mmol}\right.$ of Mo in ca. $\left.0.5 \mathrm{~mL}\right)$ with: $(a) 0.5 \mu \mathrm{L}$ (3.2 equiv.) of $\mathrm{CF}_{3} \mathrm{COOH}$; (b) $0.1 \mu \mathrm{L}$ (0.7 equiv.) of $\mathrm{CF}_{3} \mathrm{COOH}$; (c) without additives; (d) $1 \mu \mathrm{L}$ (4.1 equiv.) of $\mathrm{NEt}_{3}$; (e) $5 \mu \mathrm{L}$ (20.6 equiv.) of $\mathrm{NEt}_{3}$

The behavior of a solution of $\left[\mathrm{Cp}_{2} \mathrm{~W}_{2} \mathrm{O}_{5}\right]$ parallels quite closely that of the $\left[\mathrm{Cp}^{*}{ }_{2} \mathrm{Mo}_{2} \mathrm{O}_{5}\right]$ congener. Two peaks, a weaker one at $\delta$ 2.244 and a stronger one at $\delta 2.128$ (relative ratio: 30:70), are observed in the absence of additives, (Figure 2, spectrum $d$ ). Addition of incremental amounts of TFA caused a gradual increase of the intensity of the $\delta 2.244$ resonance, whereas the other resonance shifted downfield and decreased in intensity (position and relative intensities are $\delta 2.174$ and 49:51 in spectrum $c, \delta 2.219$ and 60:40 in spectrum $b, \delta 2.210$ and 66:34 in spectrum $a$ ). In the last solution, the estimated residual acid concentration is $0.6 \mathrm{M}$ for a $\mathrm{pH}$ of ca. 0.2 and the strong acidity may have an effect on the resonance positions (the downfield resonance, which remains unshifted at $\delta$ 2.244 on going from $c$ to $b$, slightly moves to $\delta 2.228$ on going to spectrum $a$ ). Addition of $\mathrm{NEt}_{3}$ to the neutral solution, on the other hand, led to disappearance of the $\delta 2.244$ peak and to an upfield shift of the second one to $\delta 2.067$, spectrum $e$. The latter resonance corresponds to $\left[\mathrm{Cp}^{*} \mathrm{WO}_{3}\right]^{-}$, since the independent measurement of a solution of the sodium salt shows a resonance at essentially the same chemical shift $(\delta 2.064)$, spectrum $f$.



Figure 2. ${ }^{1} \mathrm{H}$ NMR spectra of the $\mathrm{Cp}^{*} \mathrm{~W}^{\mathrm{VI}}$ system in $\mathrm{D}_{2} \mathrm{O} / \mathrm{CD}_{3} \mathrm{OD}(4: 1)$. Compound $\left[\mathrm{Cp}_{2}{ }_{2} \mathrm{~W}_{2} \mathrm{O}_{5}\right]\left(7.0 \mathrm{mg}, 19.5 \cdot 10^{-3} \mathrm{mmol}\right.$ of W in ca. $\left.0.8 \mathrm{~mL}\right)$ with: (a) $40 \mu \mathrm{L}$ of $\mathrm{CF}_{3} \mathrm{COOH}$ (27 equiv); (b) $20 \mu \mathrm{L}$ of $\mathrm{CF}_{3} \mathrm{COOH}$ (13.4 equiv); (c) $10 \mu \mathrm{L}$ of $\mathrm{CF}_{3} \mathrm{COOH}$ (6.7 equiv); (d) without additives; (e) $20 \mu \mathrm{L}$ of $\mathrm{NEt}_{3}$ (7.6 equiv). (f) Compound $\mathrm{Na}\left[\mathrm{Cp} * \mathrm{WO}_{3}\right]$ (7.6 $\mathrm{mg}, 19.5 \cdot 10^{-3} \mathrm{mmol}$ in ca. $0.5 \mathrm{~mL}$ )

These NMR results can be rationalized on the basis of the established speciation of $\mathrm{Cp} * \mathrm{Mo}^{\mathrm{VI}}$ in $\mathrm{H}_{2} \mathrm{O}-\mathrm{MeOH}$ (see Introduction) and on the interconversion mechanism between the various species, as summarized in Scheme 1. ${ }^{[3 a, 5]}$ Specifically: (i) the protonation of $\left[\mathrm{Cp}^{*} \mathrm{MoO}_{3}\right]^{-}$to $\left[\mathrm{Cp} * \mathrm{MoO}_{2}(\mathrm{OH})\right]$ is faster than the time of mixing in a stopped-flow kinetics experiment (ca. $1 \mathrm{~ms}$ ), therefore proton selfexchange (equation $4, \mathrm{M}=\mathrm{Mo}$ ) should lead to a single, $\mathrm{pH}$ dependent average resonance for these two species in the fast exchange limit; (ii) the second protonation is equally fast when taking place on a second oxido ligand but is visible only at very low $\mathrm{pH}(<0)$, leading to $\left[\mathrm{Cp} * \mathrm{MoO}(\mathrm{OH})_{2}\right]^{+}$; the latter, however, slowly and irreversibly converts to a more stable dioxido-aqua complex, $\left[\mathrm{Cp} * \mathrm{MoO}_{2}\left(\mathrm{H}_{2} \mathrm{O}\right)\right]^{+}$; (iii) the latter complex equilibrates rapidly with $\left[\mathrm{Cp} * \mathrm{MoO}_{2}\right]^{+}$, hence the water exchange process must take place dissociatively and only one resonance is expected for these two species; (iv) a small amount of the neutral $\left[\mathrm{Cp} * \mathrm{MoO}_{2}(\mathrm{OH})\right]$, remains in equilibrium with the two ionic species at intermediate $\mathrm{pH}$ values.

On the basis of this knowledge, the pH-dependent high-field resonances in Figure 1 and Figure 2 are assigned to the rapidly equilibrating $\left[\mathrm{Cp}^{*} \mathrm{MO}_{3}\right]^{-/} /\left[\mathrm{Cp} * \mathrm{MO}_{2}(\mathrm{OD})\right]$ mixtures, the former compound being the only species remaining after addition of $\mathrm{NEt}_{3}$ and the latter one dominating under strongly acidic conditions. The lower field resonance, on the other hand, could be attributed to the cationic form, $\left[\mathrm{Cp} * \mathrm{MO}_{2}\left(\mathrm{D}_{2} \mathrm{O}\right)\right]^{+}$, for which the exchange with the neutral complex $\left[\mathrm{Cp}^{*} \mathrm{MO}_{2}(\mathrm{OD})\right]$ is slow on the NMR timescale. Note that, according to the previously published speciation study of the $\mathrm{Cp} * \mathrm{Mo}^{\mathrm{VI}}$ system, complex $\left[\mathrm{Cp} * \mathrm{MoO}_{2}\left(\mathrm{H}_{2} \mathrm{O}\right)\right]^{+}$should remain the only species in solution at $\mathrm{pH}<2 \cdot{ }^{[3 \mathrm{a}]}$ In the NMR study of Figure 1, a small amount of the neutral species remains present and the $\mathrm{pH}$ of the solution is estimated as ca. 2. A separate NMR spectrum recorded on a solution containing $0.4 \mathrm{mg}$ of $\mathrm{Cp}^{*}{ }_{2} \mathrm{Mo}_{2} \mathrm{O}_{5}\left(0.74 \cdot 10^{-3}\right.$ $\mathrm{mmol})$ and $59.2 \mu \mathrm{L}$ of $\mathrm{CF}_{3} \mathrm{COOH}(0.77 \mathrm{mmol})$ in $1 \mathrm{~mL}(0.2 \mathrm{~mL}$ 
$\mathrm{CD}_{3} \mathrm{OD}$ and $0.8 \mathrm{~mL} \mathrm{D}_{2} \mathrm{O}$ ), for an estimated $\mathrm{pH}$ of ca. 0.1 , showed a dominant resonance at $\delta 2.057$, which we attribute to the $\left[\mathrm{Cp} * \mathrm{MoO}_{2}\left(\mathrm{D}_{2} \mathrm{O}\right)\right]^{+}$ion, and a small shoulder at ca. $\delta 2.074$ (estimated $10 \%$ relative intensity), the nature of which is unclear. The small upfield shift of the cation resonance is likely due to the equilibrium protonation of the solvent, changing the relative chemical shift of the residual solvent $\mathrm{CHD}_{2}$ resonance that we arbitrarily considered as constant. No resonance below $\delta 2.0$ was observed in this spectrum, pointing to the absence of any residual $\mathrm{Cp} * \mathrm{MoO}_{2}(\mathrm{OD})$, in agreement with the previously published speciation study. This spectrum is shown in the supporting information section (Figure S1). A comparison between the Mo and $\mathrm{W}$ system shows that a greater amount of deuteroxido complex, $\left[\mathrm{Cp} * \mathrm{MO}_{2}(\mathrm{OD})\right]$, remains at low $\mathrm{pH}$ under comparable conditions for the $\mathrm{W}$ derivative, suggesting a greater thermodynamic acidity of $\left[\mathrm{Cp} * \mathrm{MO}_{2}\left(\mathrm{D}_{2} \mathrm{O}\right)\right]^{+}$for the system of the heavier metal.



Scheme 1. Proposed interpretation of the ${ }^{1} \mathrm{H}$ NMR results for $\left[\mathrm{Cp}_{2}{ }_{2} \mathrm{~W}_{2} \mathrm{O}_{5}\right]$ in polar donor solvents $(\mathrm{B}=$ base $)$.

$$
\begin{aligned}
& {\left[\mathrm{Cp}^{2} \mathrm{MO}_{2}(\mathrm{OH})\right]+\left[\mathrm{Cp} * \mathrm{MO}_{3}\right]^{-} } \begin{array}{c}
{\left[\mathrm{Cp} * \mathrm{MO}_{3}\right]^{-}} \\
+\left[\mathrm{Cp}^{*} \mathrm{MO}_{2}(\mathrm{OH})\right]
\end{array} \\
&(\mathrm{M}=\mathrm{Mo}, \mathrm{W})
\end{aligned}
$$

An additional point of interest is the linewidth of the averaged $\mathrm{pH}$-dependent $\left[\mathrm{Cp} * \mathrm{WO}_{2}(\mathrm{OD})\right] /\left[\mathrm{Cp} * \mathrm{WO}_{3}\right]^{-}$resonance. This resonance is sharper in the two extreme $\mathrm{pH}$ regions and becomes broader at intermediate $\mathrm{pH}$ (Figure 2, spectrum $c$ ). The likely reason for this behavior is that the rate of degenerate proton transfer equilibrating the two species (equation 4) is not much greater than the chemical shift difference.

In conclusion, the results of the NMR investigation are in full agreement with the previously established speciation behavior of the $\mathrm{Cp} * \mathrm{Mo}^{\mathrm{VI}}$ system and indicate that the corresponding $\mathrm{Cp}^{*} \mathrm{~W}^{\mathrm{VI}}$ system behaves qualitatively in the same way, the major difference being its slightly higher acidity.

\section{(b) Investigation of the $\mathrm{Cp}^{*} \mathrm{M}^{\mathrm{VI}}$ systems in $\mathrm{CD}_{3} \mathrm{OD}$}

It is convenient to first analyze the behavior of $\left[\mathrm{Cp}_{2}{ }_{2} \mathrm{M}_{2} \mathrm{O}_{5}\right]$ in $\mathrm{CD}_{3} \mathrm{OD}$ as a function of the addition of water, because of the difference in electrical conductivity observed between pure methanol and the methanol-water mixture (see section 1 above).

The spectra of $\mathrm{Cp}^{*}{ }_{2} \mathrm{Mo}_{2} \mathrm{O}_{5}$ in variable mixtures of $\mathrm{D}_{2} \mathrm{O} / \mathrm{CD}_{3} \mathrm{OD}$ are shown in Figure 3. The dinuclear compounds shows a single resonance in the pure solvent at $\delta 2.045$ (spectrum $a$ ). After the first addition of $\mathrm{D}_{2} \mathrm{O}$, the compound started to precipitate from solution, thus all subsequent spectra were recorded on saturated solutions. The resonance gradually shifted downfield and decreased in intensity, while a new resonance appeared and gradually increased in intensity and shifted upfield as the amount of $\mathrm{D}_{2} \mathrm{O}$ increased. The two resonances converged in relative intensity and positions to those observed for the 80:20 mixture and reported in Figure 1, spectrum $c$.

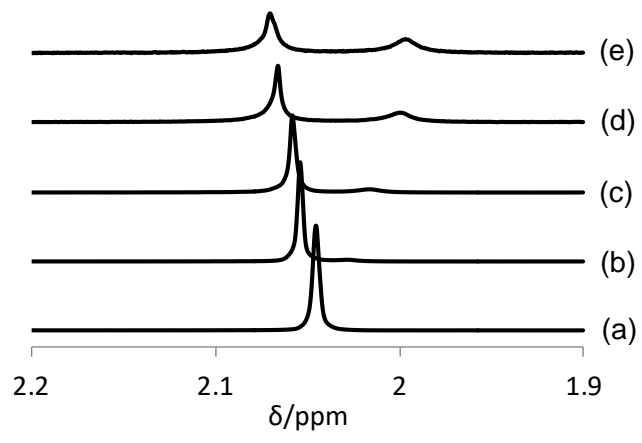

Figure 3. ${ }^{1} \mathrm{H}$ NMR spectra of $\left[\mathrm{Cp}_{2}{ }_{2} \mathrm{Mo}_{2} \mathrm{O}_{5}\right]\left(5 \mathrm{mg}, 18.4 \cdot 10^{-3} \mathrm{mmol}\right.$ of $\mathrm{Mo}$ ) in $\mathrm{CD}_{3} \mathrm{OD}$ $(0.5 \mathrm{~mL})$ after the progressive addition of $\mathrm{D}_{2} \mathrm{O}\left(\mathrm{CD}_{3} \mathrm{OD} / \mathrm{D}_{2} \mathrm{O}\right.$ ratio in parentheses. $(a)$ No $\mathrm{D}_{2} \mathrm{O}$ (100:0). (b) $0.2 \mathrm{~mL}$ (71:29). (c) $0.4 \mathrm{~mL}$ (56:44). (d) $0.7 \mathrm{~mL}$ (42:58). (e) $1 \mathrm{~mL}$ (33:67).

On the basis of the discussion in the previous section, the new resonance can be attributed to the rapidly exchanging $\left[\mathrm{Cp} * \mathrm{MoO}_{2}(\mathrm{OD})\right] /\left[\mathrm{Cp} * \mathrm{MoO}_{3}\right]^{-}$pair, in agreement with the expected increasing degree of dimer splitting according to equation $5(\mathrm{M}=$ Mo) and with the expected increasing degree of ionic dissociation as the amount of $\mathrm{D}_{2} \mathrm{O}$ increases. The behavior of the other resonance, however, is unexpected, because if the ionic dissociation is slow as indicated in Scheme 1, three rather than two resonances should be visible, one for the anion (rapidly exchanging with the neutral hydroxido complex), one for the cation and one for the neutral dinuclear precursor. A rapid dissociation, on the other hand, should result in a single resonance. The observed behavior indicates a rapid exchange between the neutral dinuclear system and the cation, without the intervention of the anion.

$$
\begin{aligned}
& {\left[\mathrm{Cp}^{*} \mathrm{M}_{2} \mathrm{O}_{5}\right]+\mathrm{D}_{2} \mathrm{O} \rightleftarrows } 2 \mathrm{Cp}^{*} \mathrm{MO}_{2}(\mathrm{OD}) \\
&(\mathrm{M}=\mathrm{Mo}, \mathrm{W})
\end{aligned}
$$

This phenomenon may be rationalized by the presence of an associative exchange through the trinuclear $\left[\mathrm{Cp}_{2}{ }_{2} \mathrm{Mo}_{3} \mathrm{O}_{7}\right]^{+}$cation, as indicated in Scheme 2. The $\left[\mathrm{Cp}^{*} \mathrm{MoO}_{2}\left(\mathrm{D}_{2} \mathrm{O}\right)\right]^{+}$ion is in rapid equilibrium with $\left[\mathrm{Cp} * \mathrm{MoO}_{2}\right]^{+}$, which is capable to add to the neutral dinuclear compound. Note that the proposed associative $\left[\mathrm{Cp}_{3} \mathrm{Mo}_{3} \mathrm{O}_{7}\right]^{+}$intermediate has indeed been experimentally observed, among other species including $\left[\mathrm{Cp}^{*} \mathrm{MoO}_{2}\right]^{+}$and $\left[\mathrm{Cp}^{*} \mathrm{MoO}_{2}\left(\mathrm{H}_{2} \mathrm{O}\right)\right]^{+}$, by an electrospray ionization MS experiment of a $\mathrm{MeOH}-\mathrm{H}_{2} \mathrm{O}(50: 50)$ solution of $\left[\mathrm{Cp}^{*}{ }_{2} \mathrm{Mo}_{2} \mathrm{O}_{5}\right] .{ }^{[11]}$ The existence of this ion in the gas phase does not necessarily mean that it will be stable in solution, but proves that it is a local energy minimum on the potential energy surface and can therefore be involved as a reaction intermediate. Therefore, the lower field resonance in Figure 
3 is attributed to the rapidly exchanging $\left[\mathrm{Cp}^{*} \mathrm{MoO}_{2}\left(\mathrm{D}_{2} \mathrm{O}\right)\right]^{+} /$ $\left[\mathrm{Cp}{ }_{2} \mathrm{Mo}_{2} \mathrm{O}_{5}\right]$ mixture. The resonance observed in $\mathrm{CD}_{3} \mathrm{OD}-\mathrm{D}_{2} \mathrm{O}$ $20: 80$ at $\delta 2.077$ (Figure 1, spectra $a-c$ ), attributed above to the pure $\left[\mathrm{Cp} * \mathrm{MoO}_{2}\left(\mathrm{D}_{2} \mathrm{O}\right)\right]^{+}$ion, may in fact still contain a residual component of undissociated neutral $\left[\mathrm{Cp}_{2}{ }_{2} \mathrm{Mo}_{2} \mathrm{O}_{5}\right]$ complex.

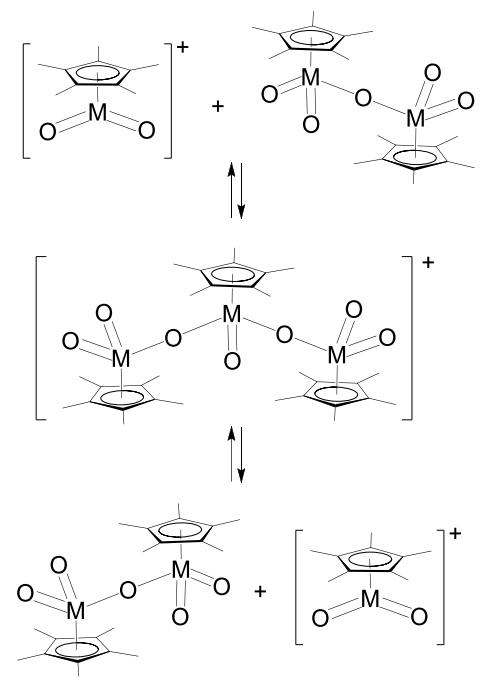

Scheme 2. Mechanism of the associative exchange of $\left[\mathrm{Cp}^{*} \mathrm{MoO}_{2}\right]^{+}$cations with the $\left[\mathrm{Cp}_{2}{ }_{2} \mathrm{Mo}_{2} \mathrm{O}_{5}\right]$ compound.

A second ${ }^{1} \mathrm{H}$ NMR study as a function of $\mathrm{D}_{2} \mathrm{O} / \mathrm{CD}_{3} \mathrm{OD}$ ratio was carried out as above, except that this time the added $\mathrm{D}_{2} \mathrm{O}$ contained $0.1 \mathrm{M}$ TFA. The resulting spectra are collected in Figure 4. It can be seen that the major resonance of $\left[\mathrm{Cp}_{2}{ }_{2} \mathrm{Mo}_{2} \mathrm{O}_{5}\right]$ shifts gradually downfield and decreases slightly in intensity, whereas a second resonance appears for increasing amounts of water at lower fields and also shifts further downfield, converging to the position previously assigned to the neutral complex $\left[\mathrm{Cp} * \mathrm{MoO}_{2}(\mathrm{OD})\right]$. The final spectrum (spectrum $e$, corresponding to a $80: 20 \mathrm{D}_{2} \mathrm{O} / \mathrm{CD}_{3} \mathrm{OD}$ ratio) is identical to spectrum $a$ in Figure 1. This behavior is perfectly coherent with those described in Figure 1 and in Figure 3 and with the discussion presented so far. The major resonance is attributed to the rapidly exchanging $\left[\mathrm{Cp}_{2} \mathrm{Mo}_{2} \mathrm{O}_{5}\right]$ and $\left[\mathrm{Cp} * \mathrm{MoO}_{2}\left(\mathrm{D}_{2} \mathrm{O}\right)\right]^{+}$(Scheme 2) and the minor one to $\left[\mathrm{Cp} * \mathrm{MoO}_{2}(\mathrm{OD})\right]$. Since no $\left[\mathrm{Cp} * \mathrm{MoO}_{3}\right]^{-}$species should be present at this $\mathrm{pH}$, the shift of the minor resonance as a function of the $\mathrm{D}_{2} \mathrm{O} / \mathrm{CD}_{3} \mathrm{OD}$ ratio must be the result of a solvent effect, possibly related to stronger hydrogen bonding in the presence of greater amounts of water.

The analogous experiment on compound $\left[\mathrm{Cp}_{2}{ }_{2} \mathrm{~W}_{2} \mathrm{O}_{5}\right]$ gives a significantly different behavior. The $\mathrm{CD}_{3} \mathrm{OD}$ solution already shows two resonances (A and $\mathrm{B}$ ), even before the addition of water, at $\delta$ 2.211 and 2.184 in a ca. 29:71 ratio, see Figure 5, spectrum $a$. The addition of small amounts of $\mathrm{D}_{2} \mathrm{O}$ (spectra in the upper figure) induces a downfield shift for both resonances and a dramatic intensity redistribution with an increase of A and a decrease of B. In addition, a new resonance (C) appears upfield. Increasing the amount of water further shifts all resonances downfield, with $\mathrm{C}$ increasing in intensity. When the amount of added water becomes very large, however (spectra in the lower figure), resonance B completely disappears and resonance A decreases again in intensity in favor of resonance $\mathrm{C}$, which now shifts upfield. Comparison of this behavior with that of $\left[\mathrm{Cp}^{*}{ }_{2} \mathrm{Mo}_{2} \mathrm{O}_{5}\right]$ in Figure 3 leads to the straightforward assignment of resonance $\mathrm{A}$ to the rapidly exchanging $\left[\mathrm{Cp}^{*}{ }_{2} \mathrm{~W}_{2} \mathrm{O}_{5}\right] /\left[\mathrm{Cp} * \mathrm{WO}_{2}\left(\mathrm{D}_{2} \mathrm{O}\right)\right]^{+}$mixture, richer in the former at low $\mathrm{D}_{2} \mathrm{O}$ content and in the latter in strongly aqueous solutions, whereas the new resonance $\mathrm{C}$ is assigned to the rapidly exchanging $\left[\mathrm{Cp}^{*} \mathrm{WO}_{2}(\mathrm{OD})\right] /\left[\mathrm{Cp}^{*} \mathrm{WO}_{3}\right]^{-}$. Like in the Mo case, the addition of greater amounts of $\mathrm{D}_{2} \mathrm{O}$ induces greater dimer dissociation (equation 5, M $=\mathrm{W}$ ) and greater degree of ionic dissociation.

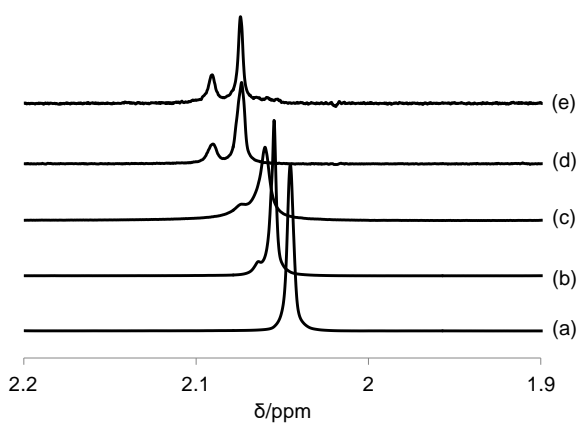

Figure 4. ${ }^{1} \mathrm{H}$ NMR spectra of $\left[\mathrm{Cp}_{2}{ }_{2} \mathrm{Mo}_{2} \mathrm{O}_{5}\right]\left(2 \mathrm{mg}, 7.4 \cdot 10^{-3} \mathrm{mmol}\right.$ of $\left.\mathrm{Mo}\right)$ in $\mathrm{CD}_{3} \mathrm{OD}(0.4$ $\mathrm{mL})$ after the progressive addition of a $0.1 \mathrm{M}$ solution of TFA in $\mathrm{D}_{2} \mathrm{O}\left(\mathrm{CD}_{3} \mathrm{OD} / \mathrm{D}_{2} \mathrm{O}\right.$ ratio in parentheses. (a) No TFA- $\mathrm{D}_{2} \mathrm{O}$ (100:0). (b) $0.2 \mathrm{~mL}$ (67:33). (c) $0.4 \mathrm{~mL}$ (50:50). (d) $1.0 \mathrm{~mL}$ (29:71). (e) $1.6 \mathrm{~mL}(20: 80)$.


Figure 5. ${ }^{1} \mathrm{H}$ NMR spectra of $\left[\mathrm{Cp}^{*}{ }_{2} \mathrm{~W}_{2} \mathrm{O}_{5}\right](6.7 \mathrm{mg}, 0.019 \mathrm{mmol})$ in $\mathrm{CD}_{3} \mathrm{OD}(0.5 \mathrm{~mL})$ in the presence of variable amounts of $\mathrm{D}_{2} \mathrm{O}\left(\mathrm{CD}_{3} \mathrm{OD} / \mathrm{D}_{2} \mathrm{O}\right.$ ratio in parentheses). (a) No water (100:0). (b) $20 \mu \mathrm{L}$ (96.2:3.8). (c) $40 \mu \mathrm{L}$ (92.6:7.4). (d) $100 \mu \mathrm{L}$ (83:17). (e) $150 \mu \mathrm{L}$ (77:23). (f) $0.2 \mathrm{~mL}$ (71:29). (g) $0.4 \mathrm{~mL}(56: 44)$. (h) $0.7 \mathrm{~mL}$ (42:58). (i) $1.0 \mathrm{~mL}$ (33:67). (j) $1.5 \mathrm{~mL}(25: 75)$. The two series shown in the two separate figures correspond to two separate experiments with a different methanol source.

The strong resonance B must be a new species not involving water, but involving the methanol solvent, presumably because of its protic nature (as will be shown below, this phenomenon does not occur in coordinating aprotic organic solvents). One possible interpretation of this behavior involves the addition of methanol to yield a methoxido derivative, either in a mononuclear or in a 
dinuclear form, see Scheme 3. The dinuclear formulation would seem justified by the known stronger Lewis acidity of $\mathrm{Cp}^{*} \mathrm{~W}^{\mathrm{VI}}$ relative to $\mathrm{Cp} * \mathrm{Mo}^{\mathrm{VI}}$. Related known reactivity patterns in support of this behavior are the cycloaddition reactions observed for $\left[\mathrm{Cp} * \mathrm{WO}_{3}\right]^{-}$, but not for $\left[\mathrm{Cp}^{*} \mathrm{MoO}_{3}\right]^{-}$, with the ketene $\mathrm{PhCH}=\mathrm{C}=\mathrm{O}$ and the alkyne $\mathrm{MeO}_{2} \mathrm{CC} \equiv \mathrm{CCO}_{2} \mathrm{Me},{ }^{[10 b]}$ leading to isolated products having a coordination sphere of type $\left[\mathrm{Cp} * \mathrm{WO}_{2} \mathrm{X}_{2}\right]^{-}$and therefore isoelectronic with that of $\left[\mathrm{Cp} * \mathrm{WO}_{2}(\mu-\mathrm{OMe})\right]_{2}$. Another example is the addition of thioglycolic acid to $\left[\mathrm{Cp}_{2}{ }_{2} \mathrm{~W}_{2} \mathrm{O}_{5}\right]$ to yield $\left[\mathrm{Cp} * \mathrm{WO}(\mathrm{OH})\left(\mathrm{k}^{2}: S, O-\mathrm{SCH}_{2} \mathrm{COO}\right)\right],{ }^{[12]}$ whereas no adduct is generated from $\left[\mathrm{Cp}^{*}{ }_{2} \mathrm{Mo}_{2} \mathrm{O}_{5}\right]$. The nature of this product has been further investigated by computational methods, which strongly militate in favor of a mononuclear formulation (see later).

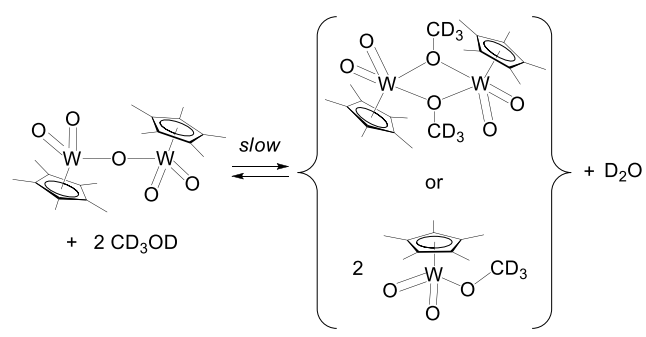

Scheme 3. Proposed equilibrium accounting for resonances A and B in the spectra of Figure 5.

The proposed equilibrium of Scheme 3 must be slow on the NMR time scale because resonances $\mathrm{A}$ and $\mathrm{B}$ are individually observed in neat methanol. Given this proposed behavior, it is also reasonable to wonder whether species $\left[\mathrm{Cp} * \mathrm{WO}_{2}(\mathrm{OD})\right]$ equally adopts a dimeric rather than a monomeric form. The monomeric form, however, appears likely in view of the observed fast degenerate exchange with the anion (equation 4) and in consideration of the lower donor power of $\mathrm{OH}(\mathrm{OD})$ relative to $\mathrm{OMe}$ $\left(\mathrm{OCD}_{3}\right)$.

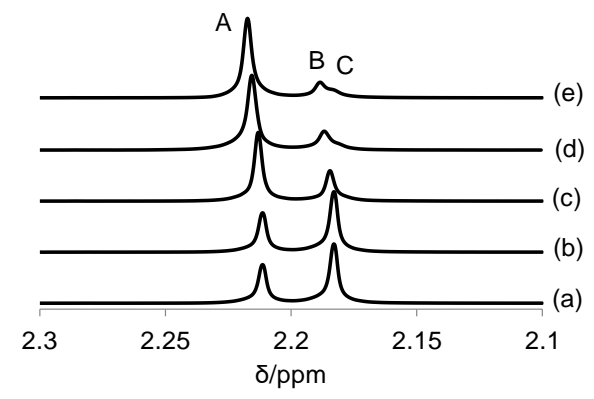

Figure 6. ${ }^{1} \mathrm{H}$ NMR spectra of $\left[\mathrm{Cp}^{*}{ }_{2} \mathrm{~W}_{2} \mathrm{O}_{5}\right](10 \mathrm{mg}, 0.014 \mathrm{mmol})$ in $\mathrm{CD}_{3} \mathrm{OD}(0.5 \mathrm{~mL})$ in the presence of variable amounts of $\mathrm{D}_{2} \mathrm{O}$ under acidic conditions. (a) No $\mathrm{D}_{2} \mathrm{O}$. (b) same as $a$, after addition of $2.5 \mu \mathrm{L}$ of neat $\mathrm{CF}_{3} \mathrm{COOH}(0.033 \mathrm{mmol}, 2.4$ equiv). (c) $+10 \mu \mathrm{L}$ $\mathrm{D}_{2} \mathrm{O}$ (0.56 mmol, 40 equiv). (d) $+30 \mu \mathrm{L} \mathrm{D}_{2} \mathrm{O}$ (1.7 mmol, 120 equiv). (e) $+50 \mu \mathrm{L} \mathrm{D}_{2} \mathrm{O}$ (2.8 mmol, 200 equiv).

Addition of the strong acid TFA to a neat $\mathrm{CD}_{3} \mathrm{OD}$ solution does not change the shape of the ${ }^{1} \mathrm{H}$ NMR spectrum, see spectrum $b$ vs. $a$ in Figure 6. This is consistent with the assignment of the two resonances to the species in Scheme 3 and also shows that the protonation process leading to the cationic $\left[\mathrm{Cp}^{*} \mathrm{MoO}_{2}\right]^{+}$species (possibly stabilized by solvent coordination) is not accessible in the absence of water. Addition to this solution of small amounts of $\mathrm{D}_{2} \mathrm{O}$ shows, as also found for the experiment under neutral conditions in Figure 5, an immediate intensity decrease for resonance B in favor of resonance $\mathrm{A}$, and the appearance of resonance $\mathrm{C}$ after the addition of only $10 \mu \mathrm{L}$ of $\mathrm{D}_{2} \mathrm{O}$. It is not possible to exclude that the initial solution already contains minor amounts of water, the presence of which is also suggested by the behavior in the presence of base, which is now described. The different position of resonance $\mathrm{C}$ in this experiment relative to the experiment in Figure 5 is consistent with its proposed assignment to the exchanging $\left[\mathrm{Cp} * \mathrm{WO}_{2}(\mathrm{OD})\right] /\left[\mathrm{Cp} * \mathrm{WO}_{3}\right]^{-}$pair, since a greater amount of the neutral $\left[\mathrm{Cp} * \mathrm{WO}_{2}(\mathrm{OD})\right]$ compound is present under acidic conditions.

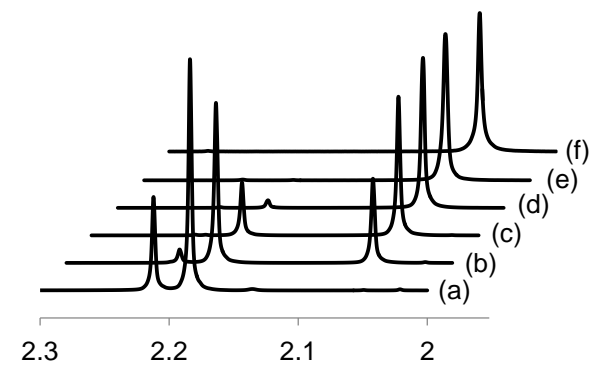

Figure 7. ${ }^{1} \mathrm{H}$ NMR spectra in $\mathrm{CD}_{3} \mathrm{OD}$. (a) Compound $\left[\mathrm{Cp}^{2}{ }_{2} \mathrm{~W}_{2} \mathrm{O}_{5}\right](20 \mathrm{mg}, 0.057 \mathrm{mmol}$ of $\mathrm{W}$ in $1.0 \mathrm{~mL})$. (b-e): same as $a$, after addition of the following amounts of neat $\mathrm{Et}_{3} \mathrm{~N}$ : (b) $1 \mu \mathrm{L}$ ( $0.0074 \mathrm{mmol}, 0.13$ equiv), (c) $5 \mu \mathrm{L}$ ( 0.037 mmol, 0.65 equiv), (d) $25 \mu \mathrm{L}$ (0.185 mmol, 3.2 equiv), (e) $200 \mu \mathrm{L}$ (1.48 mmol, 26 equiv). (f) Compound $\mathrm{Na}\left[\mathrm{Cp} * \mathrm{WO}_{3}\right](4 \mathrm{mg}, 0.0123 \mathrm{mmol}$ in $0.5 \mathrm{~mL})$

The behavior of the $\mathrm{Cp}^{*} \mathrm{~W}^{\mathrm{VI}}$ system in the presence of base $\left(\mathrm{Et}_{3} \mathrm{~N}\right)$ in neat $\mathrm{CD}_{3} \mathrm{OD}$ is shown in Figure 7. Spectrum $a$ corresponds once again to the starting material $\left[\mathrm{Cp}_{2} \mathrm{~W}_{2} \mathrm{O}_{5}\right]$, with the two resonances assigned to the pentaoxido compound itself at $\delta 2.211$ and that assigned to $\left[\mathrm{Cp} * \mathrm{WO}_{2}(\mathrm{OMe})\right]_{\mathrm{x}}$ at $\delta 2.184$. The addition of incremental amounts of $\mathrm{Et}_{3} \mathrm{~N}$ (spectra $b$ to $e$ ) led to the decrease and eventual disappearance of both resonances and to the corresponding growth of a new resonance at $\delta 2.062$, attributed of the free anion. Indeed, compound $\mathrm{Na}\left[\mathrm{Cp} * \mathrm{WO}_{3}\right]$ exhibits a single resonance at $\delta$ 2.060 in the same solvent (Figure 7, spectrum $f$ ). The addition of a substoichiometric amount of $\mathrm{NEt}_{3}$ (spectra $b$ and $c$ ) generates an essentially equivalent amount of the $\left[\mathrm{Cp} * \mathrm{WO}_{3}\right]^{-}$ion while the intensity of the peaks attributed to $\left[\mathrm{Cp}_{2}{ }_{2} \mathrm{~W}_{2} \mathrm{O}_{5}\right]$ and $\left[\mathrm{Cp} * \mathrm{WO}_{2}(\mathrm{OMe})\right]_{\mathrm{x}}$ decreases without shifting. Eventually, both these peaks disappear in the final spectrum $e$ where $\left[\mathrm{Cp} * \mathrm{WO}_{3}\right]^{-}$remains the only visible species, although this requires a greater than stoichiometric amount of Et $3 \mathrm{~N}$. The slight difference between the chemical shifts of the anion in spectra $e$ and $f$ is obviously resulting from the different counterion for the $\left[\mathrm{Cp} * \mathrm{WO}_{3}\right]^{-}$complex $\left(\mathrm{NHEt}_{3}{ }^{+}\right.$ for spectrum $e, \mathrm{Na}^{+}$for spectrum $f$ ). More specifically, since there is no indication of an ion pairing interaction between $\mathrm{Na}^{+}$and $\left[\mathrm{Cp} * \mathrm{WO}_{3}\right]^{-}$in this solvent ( $c f$. in the other solvents examined later, where the situation is quite different), it is likely that a slight shift for the ammonium salt towards lower field is caused by a labile $\mathrm{H}$ bonding between the anion oxido ligands and the ammonium proton, which has the effect of reducing the anion electron density. Given the highly dissociating power of $\mathrm{CD}_{3} \mathrm{OD}$, however, this effect is barely perceptible ( $c f$. the very different situation in $\mathrm{CD}_{3} \mathrm{CN}$ and acetone- $d_{6}$, described later).

Conversion of compound $\left[\mathrm{Cp}^{*} \mathrm{~W}_{2} \mathrm{O}_{5}\right]$ to the anion $\left[\mathrm{Cp}^{*} \mathrm{WO}_{3}\right]^{-}$ requires $\mathrm{H}_{2} \mathrm{O}$ in order to deliver one extra oxygen atom per two W 
atoms and the protons needed to convert $\mathrm{Et}_{3} \mathrm{~N}$ to the ammonium cation $\mathrm{Et}_{3} \mathrm{NH}^{+}$(equation $6, \mathrm{M}=\mathrm{W}$ ). An alternative source of protons (deuterons) is the methanol solvent, but in that case the eventual formation of $\left[\mathrm{Cp}^{*} \mathrm{WO}_{3}\right]^{-}$as the sole species would require the formation of dimethylether. Addition of $\mathrm{Et}_{3} \mathrm{~N}$ to a $\mathrm{CD}_{3} \mathrm{OD}$ solution of $\left[\mathrm{Cp}_{2}{ }_{2} \mathrm{Mo}_{2} \mathrm{O}_{5}\right]$ results in a smooth conversion to the $\left[\mathrm{Cp} * \mathrm{MoO}_{3}\right]^{-}$anion according to the same equation $6(\mathrm{M}=\mathrm{Mo})$, which is characterized by a single resonance at $\delta 1.938$ in this solvent.

$$
\left[\mathrm{Cp}_{2}{ }_{2} \mathrm{M}_{2} \mathrm{O}_{5}\right]+2 \mathrm{Et}_{3} \mathrm{~N}+\mathrm{H}_{2} \mathrm{O} \rightleftarrows 2\left[\mathrm{Et}_{3} \mathrm{NH}\right]^{+}\left[\mathrm{Cp}^{*} \mathrm{MO}_{3}\right]^{-}
$$

\section{(c) Investigation of the $\mathrm{Cp}^{*} \mathrm{M}^{\mathrm{VI}}$ systems in $\mathrm{CD}_{3} \mathrm{SOCD}_{3}$}

The behavior in DMSO- $d_{6}$ is similar in many respects to that observed in $\mathrm{CD}_{3} \mathrm{OD}$. Only the behavior of the $\mathrm{Cp} * \mathrm{~W}^{\mathrm{VI}}$ system will be described in detail. The $\left[\mathrm{Cp}^{*} \mathrm{~W}_{2} \mathrm{O}_{5}\right]$ solution exhibits two resonances, a major one at $\delta 2.075$ and a minor one at $\delta 2.034$, in a relative 86:14 ratio (Figure 8 , spectrum $a$ ). Upon $\mathrm{D}_{2} \mathrm{O}$ addition, the downfield resonance decreased in intensity in favor of the upfield resonance, from $78 \%$ in the absence of added water (spectrum $a$ ) to $64 \%$ in the presence of $50 \mu \mathrm{L}$ (spectrum $c$ ). The relative intensity change is less dramatic than that observed in methanol (Figure 5) and the interpretation of this phenomenon must also be different, because DMSO is not a protic solvent. The upfield peak is attributed to compound $\left[\mathrm{Cp}^{*} \mathrm{WO}_{2}(\mathrm{OD})\right]$ and its presence in the initial solution before $\mathrm{D}_{2} \mathrm{O}$ addition (as the $\left[\mathrm{Cp} * \mathrm{WO}_{2}(\mathrm{OH})\right]$ isotopomer), is due to the contamination of the NMR solvent with a significant amount of water. Indeed, integration of the water peak indicates that the initial solution contained ca. 7 equiv of water per $\mathrm{Cp} * \mathrm{~W}$ unit (under the assumption that this water contains deuterium at natural abundance), vs. 107 equiv after the addition of $50 \mu \mathrm{L}$ of $\mathrm{D}_{2} \mathrm{O}$ (total amount of water isotopomers). It is also interesting to note that both resonances are slightly upfield shifted (to ca. $\delta 2.055$ and 2.022) and broadened by the water addition. This can tentatively be attributed to the establishment of H-bond equilibria with water adducts. The relative amount of the $\left[\mathrm{Cp}^{*} \mathrm{WO}_{2}(\mathrm{OD})\right]$ compound, for comparable additions of $\mathrm{D}_{2} \mathrm{O}$, is greater in DMSO- $d_{6}$ relative to $\mathrm{CD}_{3} \mathrm{OD}$, suggesting that the equilibrium constant of reaction 5 is greater in DMSO. The spectrum of $\left[\mathrm{Cp}_{2}{ }_{2} \mathrm{Mo}_{2} \mathrm{O}_{5}\right]$ in neat DMSO- $d_{6}$ also shows a second peak, which is therefore tentatively assigned to the mononuclear hydroxide derivative $\left[\mathrm{Cp} * \mathrm{MoO}_{2}(\mathrm{OH})\right]$, at higher fields $(\delta 1.921)$ relative to the resonance of the dinuclear compound at $\delta$ 1.931 (see Figure S2).

Addition of $\mathrm{CF}_{3} \mathrm{COOH}$ to the $\left[\mathrm{Cp}_{2}{ }_{2} \mathrm{~W}_{2} \mathrm{O}_{5}\right]$ solution in DMSO- $d_{6}$ did not have any effect on the position and relative intensity of the two resonances, like for the experiment in $\mathrm{CD}_{3} \mathrm{OD}$. This attests to the resistance of both $\left[\mathrm{Cp}_{2} \mathrm{~W}_{2} \mathrm{O}_{5}\right]$ and $\left[\mathrm{Cp} * \mathrm{WO}_{2}(\mathrm{OD})\right]$ to protonation to yield $\left[\mathrm{Cp}^{*} \mathrm{WO}_{2}\left(\mathrm{D}_{2} \mathrm{O}\right)\right]^{+}$. The effect of the addition of incremental amounts of $\mathrm{Et}_{3} \mathrm{~N}$ is illustrated in Figure 9. Spectrum $a$ is once again the reference spectrum in the neat solvent. Progressive addition of $\mathrm{Et}_{3} \mathrm{~N}$ (spectra $b-e$ ) leads to an intensity decrease for the $\delta$ 2.075 resonance until disappearance without significant chemical shift change, whereas the $\delta 2.034$ resonance shifted to much higher field ( $\delta 1.91-1.85$ range), progressively increasing in intensity and converging to $\delta 1.855$, which is assigned to the free $\left[\mathrm{Cp}^{*} \mathrm{WO}_{3}\right]^{-}$ion. For comparison, the DMSO- $d_{6}$ solution of the $\mathrm{Na}\left[\mathrm{Cp}^{*} \mathrm{WO}_{3}\right]$ salt exhibits a single resonance at $\delta 1.800$ (Figure 9, spectrum $f$ ). The interpretation of the behavior in this solvent is straightforward, given the above described behavior in water and methanol and the assignment of the two resonances in the neutral solution to $\left[\mathrm{Cp}_{2} \mathrm{~W}_{2} \mathrm{O}_{5}\right]$ and $\left[\mathrm{Cp} * \mathrm{WO}_{2}(\mathrm{OD})\right]$. As base is added, $\left[\mathrm{Cp}_{2} \mathrm{~W}_{2} \mathrm{O}_{5}\right]$ is converted to $\left[\mathrm{Cp}^{*} \mathrm{WO}_{3}\right]^{-}$(equation 6) and its resonance does not shift (like in $\mathrm{CD}_{3} \mathrm{OD}$ ) whereas the resonance of $\left[\mathrm{Cp}^{*} \mathrm{WO}_{2}(\mathrm{OD})\right]$ shifts (like in the $\mathrm{CD}_{3} \mathrm{OD}-\mathrm{D}_{2} \mathrm{O}$ 20:80 solution) because of the fast degenerative exchange with the increasing amounts of the anion until converging to the position of the pure anion. Like in $\mathrm{CD}_{3} \mathrm{OD}$, the chemical shift difference between the DMSO- $d_{6}$ solutions of $\left[\mathrm{Et}_{3} \mathrm{ND}\right]^{+}\left[\mathrm{Cp} * \mathrm{WO}_{3}\right]^{-}$and $\mathrm{Na}^{+}\left[\mathrm{Cp} * \mathrm{WO}_{3}\right]^{-}$is attributed to the different cation-anion interactions. For the $\left[\mathrm{Cp}_{2}{ }_{2} \mathrm{Mo}_{2} \mathrm{O}_{5}\right]$ solution in this solvent, addition of excess $\mathrm{Et}_{3} \mathrm{~N}$ results in a new band at $\delta 1.729$, attributed to $\left[\mathrm{Et}_{3} \mathrm{NH}\right]^{+}\left[\mathrm{Cp} * \mathrm{MoO}_{3}\right]^{-}$.

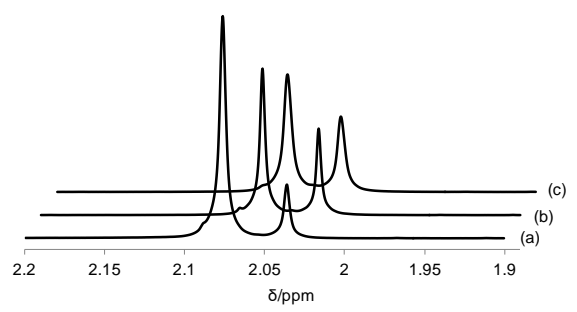

Figure 8. ${ }^{1} \mathrm{H}$ NMR spectra of $\left[\mathrm{Cp}_{2}{ }_{2} \mathrm{~W}_{2} \mathrm{O}_{5}\right](10 \mathrm{mg}, 0.028 \mathrm{mmol}$ of $\mathrm{W})$ in $\mathrm{CD}_{3} \mathrm{SOCD}_{3}$ $(0.5 \mathrm{~mL})$ in the presence of variable amounts of $\mathrm{H}_{2} \mathrm{O}$. (a) No water. (b) $30 \mu \mathrm{L}$ (1.7 mmol, 60 equiv). (c) $50 \mu \mathrm{L}$ ( $2.8 \mathrm{mmol}, 100$ equiv).

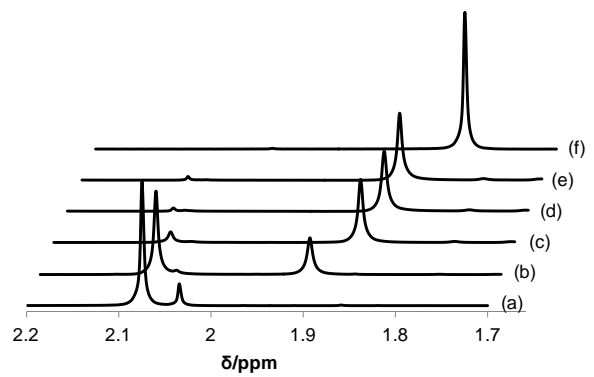

Figure 9. ${ }^{1} \mathrm{H}$ NMR spectra in $\mathrm{CD}_{3} \mathrm{SOCD}_{3}$. (a) Compound $\left[\mathrm{Cp}{ }_{2} \mathrm{~W}_{2} \mathrm{O}_{5}\right](10 \mathrm{mg}, 0.014$ $\mathrm{mmol}$ in ca. $0.5 \mathrm{~mL}) ;(b)-(e)$ same as $a$, after the incremental addition of $2 \mu \mathrm{L}(0.014$ mmol) of NEt 3 (pure, \%99). (f) Compound $\mathrm{Na}\left[\mathrm{Cp}^{*} \mathrm{WO}_{3}\right]$ (3 mg, $0.009 \mathrm{mmol} \mathrm{mmol} \mathrm{in}$ ca. $0.5 \mathrm{~mL}$ ).

\section{(d) Investigation of the $\mathrm{Cp}^{*} \mathrm{M}^{\mathrm{VI}}$ systems in $\mathrm{CD}_{3} \mathrm{COCD}_{3}$}

When dissolved in neat $\mathrm{CD}_{3} \mathrm{COCD}_{3}$ in the absence of any additive, compounds $\left[\mathrm{Cp}_{2}{ }_{2} \mathrm{M}_{2} \mathrm{O}_{5}\right]$ yield a single ${ }^{1} \mathrm{H}$ NMR resonance, observed at $\delta 2.141$ for the $\mathrm{W}$ derivative (Figure 10, spectrum $b$ ) and at $\delta 1.998$ for the Mo derivative (Figure S2). The absence of a second resonance attributable to $\left[\mathrm{Cp} * \mathrm{MO}_{2}(\mathrm{OH})\right]$ apparently results from much less favorable water addition equilibria (equation 5) in this solvent. Indeed, the initial solution contained water as revealed by ${ }^{1} \mathrm{H}$ NMR integration (ca. 1.8 equiv per metal in the $\mathrm{Cp}^{*} \mathrm{~W}^{\mathrm{VI}}$ series). Since it is possible that the $\left[\mathrm{Cp}^{*} \mathrm{MO}_{2}(\mathrm{OH})\right]$ resonance overlaps exactly with that of $\left[\mathrm{Cp}_{2}{ }_{2} \mathrm{M}_{2} \mathrm{O}_{5}\right]$, the effect of water addition to the acetone- $d_{6}$ solution was investigated as already described above in the other solvents. This experiment was carried out only for the $\mathrm{Cp}^{*} \mathrm{~W}^{\mathrm{VI}}$ system. Only after the addition of excess water (4.3 equiv per $\mathrm{Cp} * \mathrm{~W}$ unit), an additional small resonance became visible upfield of the dinuclear compound resonance, at $\delta$ 2.100 , corresponding to ca. $10 \%$ of the total $\mathrm{Cp}^{*}$ intensity (see Figure $\mathrm{S} 3$ in the Supporting Information). This resonance is therefore tentatively attributed to $\left[\mathrm{Cp} * \mathrm{WO}_{2}(\mathrm{OH})\right]$ in acetone- $d 6$. 


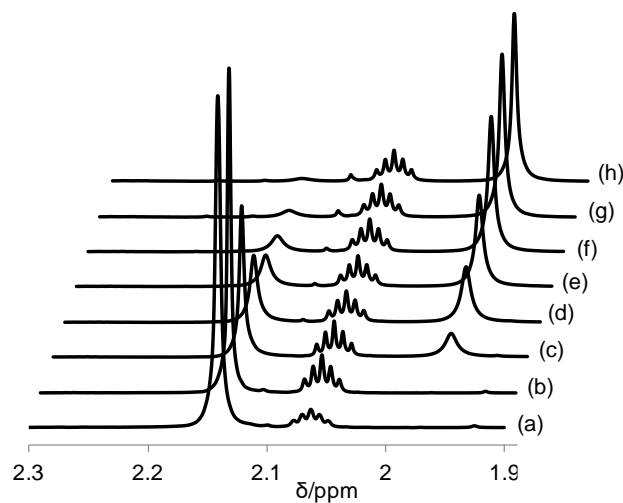

Figure 10. ${ }^{1} \mathrm{H}$ NMR spectra of compound $\left[\mathrm{Cp}_{2}{ }_{2} \mathrm{~W}_{2} \mathrm{O}_{5}\right](20.6 \mathrm{mg}, 0.0574 \mathrm{mmol}$ of W) in $\mathrm{CD}_{3} \mathrm{COCD}_{3}$ (ca. $0.5 \mathrm{~mL}$ ). (a) after addition of $1 \mu \mathrm{L}(0.013 \mathrm{mmol})$ of $\mathrm{CF}_{3} \mathrm{COOH}$ (pure, \%99); (b) without additives; $(c)$-( $h$ ), same as $b$, after incremental addition of NEt ( $2 \mathrm{M}$ in $\mathrm{CD}_{3} \mathrm{COCD}_{3}, 6.5 \mu \mathrm{L}$ for each addition, $0.013 \mathrm{mmol}$ ). The residual solvent resonance is visible as a 1:2:3:2:1 quintet at $\delta 2.063$.

As already found for the $\mathrm{CD}_{3} \mathrm{OD}$ and DMSO- $d_{6}$ solutions, addition of TFA (spectrum $a$ in Figure 10) did not alter the shape of the spectrum. Treatment of a fresh acetone- $d_{6}$ solution of $\left[\mathrm{Cp}_{2}{ }_{2} \mathrm{~W}_{2} \mathrm{O}_{5}\right]$ with incremental amounts of $\mathrm{NEt}_{3}$ gradually decreased the intensity of the $\delta 2.141$ resonance in favor of a new resonance at $\delta 1.962$ (spectra $c-h$ ). Neither of the two resonances significantly shifts as a function of the presence and amount of the base additive. By analogy with the previously presented results in $\mathrm{CD}_{3} \mathrm{OD}$ and DMSO- $d_{6}$, the single resonance observed in the neutral solution as well as in the presence of strong acid is attributed to the undissociated $\left[\mathrm{Cp}_{2} \mathrm{~W}_{2} \mathrm{O}_{5}\right]$ compound and the higher field one generated by the $\mathrm{Et}_{3} \mathrm{~N}$ addition is attributed to $\left[\mathrm{Cp}^{*} \mathrm{WO}_{3}\right]^{-}$. Like in DMSO- $d_{6}$, an excess amount of $\mathrm{Et}_{3} \mathrm{~N}$ (ca. 1.5-fold in this case) is necessary to consume the dinuclear compound quantitatively. As already discussed above, the extra $\mathrm{O}$ atom needed for the conversion of $\left[\mathrm{Cp}_{2}{ }_{2} \mathrm{~W}_{2} \mathrm{O}_{5}\right]$ into $\left[\mathrm{Cp} * \mathrm{WO}_{3}\right]^{-}$(equation 6 ) is presumably provided by the adventitious water present. This amount, however, is insufficient to produce a significant amount of $\left[\mathrm{Cp}^{*} \mathrm{WO}_{2}(\mathrm{OH})\right]$ and consequently the $\left[\mathrm{Cp} * \mathrm{WO}_{3}\right]^{-}$resonance does not shift significantly as its relative amount increases. The observed spectral changes are reversible: when the $\left[\mathrm{Cp}_{2}{ }_{2} \mathrm{~W}_{2} \mathrm{O}_{5}\right]$ solution was treated first with $\mathrm{CF}_{3} \mathrm{COOH}$ and then with excess $\mathrm{NEt}_{3}$ the resonance attributed to the $\left[\mathrm{Cp} * \mathrm{WO}_{3}\right]^{-}$anion was observed at $\delta 1.984$. Conversely, addition of excess $\mathrm{CF}_{3} \mathrm{COOH}$ to a basic solution replaced the latter resonance with that attributed to the dinuclear compound at $\delta 2.141$.

In this solvent, compound $\mathrm{Na}\left[\mathrm{Cp}^{*} \mathrm{WO}_{3}\right]$ showed a peculiar behavior (see Figure 11$)$. Surprisingly, only a small peak $(\delta 1.929)$ was observed in the region expected for free $\left[\mathrm{Cp}^{*} \mathrm{WO}_{3}\right]^{-}$, whereas a major resonance is observed at $\delta 2.846$ (relative intensities $=5: 95$, spectrum $a$ ). Suspecting the possibility that the $\mathrm{Na}^{+}$and $\left[\mathrm{Cp}^{*} \mathrm{WO}_{3}\right]^{-}$ ions engage in tight ion pairing in this solvent, the solution was treated with a stoichiometric amount of 15-crown-5, a known complexing agent for $\mathrm{Na}^{+}$. The resulting solution exhibited spectrum $b$, where the higher field resonance attributed to the free anion has increased in relative intensity (now $35 \%$ of the total) and has slightly shifted to $\delta 1.939$, whereas the lower field one has decreased in intensity, broadened, and shifted by a more substantial amount to $\delta 2.903$.

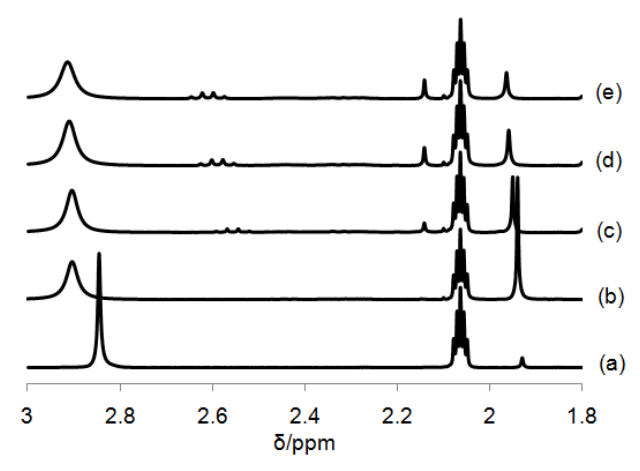

Figure 11. ${ }^{1} \mathrm{H}$ NMR spectra in $\mathrm{CD}_{3} \mathrm{COCD}_{3}$ of: (a) compound $\mathrm{Na}\left[\mathrm{Cp}^{*} \mathrm{WO}_{3}\right](4 \mathrm{mg}$, $0.0123 \mathrm{mmol}$ in $0.5 \mathrm{~mL})$; (b) same as $a$, after addition of 15 -crown-5 $(2.5 \mu \mathrm{L}, 0.0126$ mmol); (c)-(e) same as $b$, after addition of 1,2 and 3 aliquots of $\mathrm{Et}_{3} \mathrm{NH}^{+} \mathrm{Cl}^{-}(100 \mu \mathrm{L}$ of a $0.0123 \mathrm{M}$ solution in $\mathrm{CD}_{3} \mathrm{COCD}_{3}, 1.23 \mathrm{mmol}$ each).

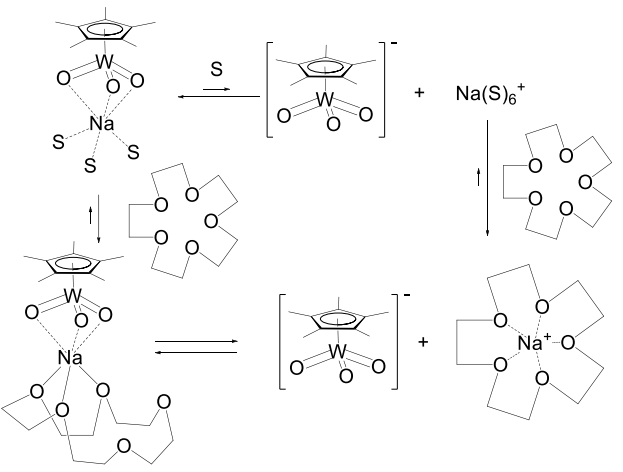

Scheme 4. Effect of 15 -crown-5 on the ion pairing equilibrium between the $\mathrm{Na}^{+}$and $\left[\mathrm{Cp} * \mathrm{WO}_{3}\right]^{-}$ions $(\mathrm{S}=$ donor solvent $)$.

This behavior confirms the assignment of the higher field resonance to the free (solvated) $\left[\mathrm{Cp}^{*} \mathrm{WO}_{3}\right]^{-}$ion and the lower field one to a tight ion pair, the structure of which is probably as depicted in Scheme 4. The strong deshielding of the anion $\mathrm{Cp}^{*}$ resonance induced by ion pairing suggests a significant electron density removal from the $\mathrm{Cp}^{*}$ ligand, transmitted through the $\mathrm{W}=\mathrm{O}$ bonds. The observation of two distinct resonances for the free anion and the ion pair shows that the equilibrium is slow on the NMR timescale. In addition, the chemical shift dependence and broadening of the resonance attributed to the ion pair in the presence of the crown ether suggests that the sodium ion interacts with the crown ether not only as free cation but also in the ion pair, as suggested in Scheme 4. The broadening effect is presumably the result of rapid equilibria between structures having a different denticity $\left(\kappa^{3}, \kappa^{2}, \kappa^{1}\right)$ for the crown ether coordination. However, the crown ether must be coordinating more strongly to free $\mathrm{Na}^{+}$, because its addition increases the amount of free $\left[\mathrm{Cp}^{*} \mathrm{WO}_{3}\right]^{-}$. These results also indicate that the $\left[\mathrm{Cp}^{*} \mathrm{WO}_{3}\right]^{-}$anion is a strong complexing agent for $\mathrm{Na}^{+}$, since it effectively competes with the crown ether for sodium. In fact, the equilibrium of Scheme 4 remains shifted to the left hand side with the crown ether and $\left[\mathrm{Cp}^{*} \mathrm{WO}_{3}\right]^{-}$being present in equimolar amounts.

It is useful to compare the properties of the three solvents examined so far. In terms of dielectric constant, the most dissociating solvent is DMSO $(\varepsilon=46.8)$, followed by methanol $(\varepsilon=$ $32.6)$ and acetone $(\varepsilon=20.5)$. The solvent dissociating power for the ion pair is probably also influenced by the coordinating power with 
respect to the $\mathrm{Na}^{+}$ion, which is presumably strongest for methanol. However, the observed behavior is perfectly consistent with the dielectric behavior of the medium. It should also be noted that addition of 15 -crown- 5 to the DMSO- $d_{6}$ and $\mathrm{CD}_{3} \mathrm{OD}$ solutions of $\mathrm{Na}\left[\mathrm{Cp} * \mathrm{WO}_{3}\right]$ did not cause any change to the $\mathrm{Cp} *$ resonance.

We have also investigated the ${ }^{1} \mathrm{H}$ NMR spectrum of the $\mathrm{Na}\left[\mathrm{Cp} * \mathrm{WO}_{3}\right] / 15$-crown-5 solution after addition of incremental amounts of $\mathrm{Et}_{3} \mathrm{NH}^{+} \mathrm{Cl}^{-}$, because the $\mathrm{Et}_{3} \mathrm{NH}^{+}$ion is generated in some of the solutions by subsequent addition of $\mathrm{NEt}_{3}$ and $\mathrm{CF}_{3} \mathrm{COOH}$ and a question of interest was the possible establishment of $\mathrm{H}$-bonds of type $\left[\mathrm{Cp}^{*} \mathrm{~W}^{(-)} \mathrm{O}_{3} \cdots \mathrm{HN}^{(+)} \mathrm{Et}_{3}\right]$. The $\mathrm{Et}_{3} \mathrm{NH}^{+} \mathrm{Cl}^{-}$addition had no major effect on the chemical shift of the two resonances (spectra $c-e$ ). A slight downfield shift observed for the free anion resonance to $\delta$ 1.964 may indeed be attributed to a fast equilibrium with a weak $\mathrm{H}$ bond adduct, which must however be much less stable and more labile than the adduct with sodium. Note that this chemical shift corresponds quite closely with that of the same species when this is generated from $\left[\mathrm{Cp}_{2}{ }_{2} \mathrm{~W}_{2} \mathrm{O}_{5}\right] / \mathrm{Et}_{3} \mathrm{~N}$. The $\mathrm{Et}_{3} \mathrm{NH}^{+} \mathrm{Cl}^{-}$addition, however, resulted in two additional and more important effects. The first one is a change of the equilibrium in favor of the ion pair, with the free ion/ion pair ratio becoming 20:80 after the first addition (spectrum c), 15:85 after the second one (spectrum $d$ ) and finally 13:87 after the third one (spectrum $e$ ). A possible reason for this change is a competition between $\mathrm{Na}^{+}$and $\mathrm{Et}_{3} \mathrm{NH}^{+}$for 15 -crown-5, partially restoring the equilibrium situation observed in the absence of the crown ether. The second effect of the $\mathrm{Et}_{3} \mathrm{NH}^{+} \mathrm{Cl}^{-}$addition is the appearance of the dinuclear species (resonance at $\delta 2.141$ ), which is the natural consequence of introducing protons into the system via the $\mathrm{Et}_{3} \mathrm{NH}^{+}$ion, with the concurrent production of water. The deprotonation of $\mathrm{Et}_{3} \mathrm{NH}^{+}$is also evident from the shift of the $\mathrm{Et}_{3} \mathrm{NH}^{+}$ methylene resonance between spectra $c, d$ and $e$.

The behavior of $\left[\mathrm{Cp}_{2}{ }_{2} \mathrm{Mo}_{2} \mathrm{O}_{5}\right]$ in the presence of $\mathrm{Et}_{3} \mathrm{~N}$ acetone$d_{6}$ parallels that of the $\mathrm{W}$ analogue, except that a greater amount of $\mathrm{Et}_{3} \mathrm{~N}$ is necessary for the conversion of the dinuclear compound to the anion (the spectra are shown in the Supporting Information, Figure S4). The resonance of $\left[\mathrm{Et}_{3} \mathrm{NH}\right]^{+}\left[\mathrm{Cp} * \mathrm{MoO}_{3}\right]^{-}$is observed at $\delta$ 1.867.

\section{(e) Investigation of the $\mathrm{Cp}^{*} \mathrm{M}^{\mathrm{VI}}$ systems in $\mathrm{CD}_{3} \mathrm{CN}$}

Like in acetone- $d_{6}$, the $\mathrm{Na}\left[\mathrm{Cp} * \mathrm{WO}_{3}\right]$ salt is strongly ion paired in $\mathrm{CD}_{3} \mathrm{CN}$, since it shows a major downfield shifted resonance at $\delta$ 2.185 for the tight ion pair and a minor one at $\delta 1.945$, flanking the envelope of the solvent resonance, for free $\left[\mathrm{Cp} * \mathrm{WO}_{3}\right]^{-}$(see Figure 12, spectrum $a$ ). The two species are present in a $86: 14$ ratio. The assignment is supported, like for the experiment in acetone- $d_{6}$, by the spectrum evolution after addition of a stoichiometric amount of 15-crown-5 to (spectrum $b$ ), where the relative intensity of the two resonances becomes ca. 1:1. The free ion resonance has slightly shifted upfield to $\delta 1.936$ and that of the ion pair has shifted downfield to $\delta 2.263$ and broadened, similarly to the behavior in acetone- $d_{6}$. The interpretation is therefore identical to that discussed above in acetone- $d_{6}$ section (Scheme 4). Addition of $\mathrm{Et}_{3} \mathrm{NH}^{+}$gave again indication of an insignificant interaction with the free trioxido anion (the resonance shifted only slightly to $\delta 1.941$ ), while the ion pair resonance further broadened and slightly increased in relative intensity. The dielectric constant of acetonitrile $(\varepsilon=35.7)$ is greater than that of acetone and similar to that of methanol. Evidently, the lower coordinating power of $\mathrm{MeCN}$ toward $\mathrm{Na}^{+}$relative to methanol must be an important factor for the ion pair separation.

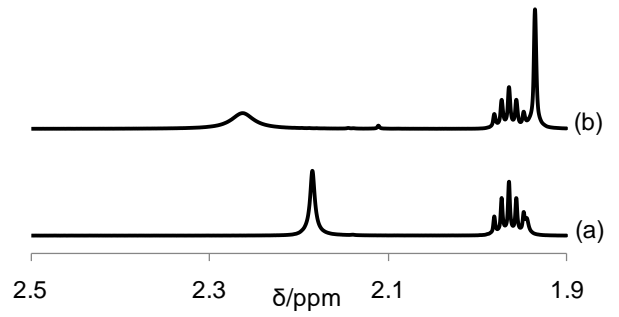

Figure 12. ${ }^{1} \mathrm{H}$ NMR spectra in $\mathrm{CD}_{3} \mathrm{CN}$ of: (a) compound $\mathrm{Na}\left[\mathrm{Cp} * \mathrm{WO}_{3}\right]$ (4 mg, 0.0123 mmol in ca. $0.5 \mathrm{~mL})$; (b) same as $a$, after addition of 15 -crown-5 $(2.5 \mu \mathrm{L}, 0.0123 \mathrm{mmol})$. The residual solvent resonance is visible as a 1:2:3:2:1 quintet at $\delta 1.965$.

Compounds $\left[\mathrm{Cp}^{*}{ }_{2} \mathrm{M}_{2} \mathrm{O}_{5}\right]$ exhibit a single resonance in $\mathrm{CD}_{3} \mathrm{CN}$ at $\delta 2.139$ (W, Figure 13, spectrum $a$ ) and 1.994 (Mo, Figure S2). The spectra exhibit also a second minor resonance at ca. $\delta 2.17$, due to the water contaminant in the solvent. This was proven by a study of the addition of water to the $\mathrm{W}$ sample, resulting in a dramatic and continuous shift of this resonance to lower fields (see Figure S5 in the supporting information). Addition of water also resulted in the appearance of a very small new resonance slightly upfield of the dinuclear compound resonance, also shown in Figure S5 (at $\delta 2.116$ for ca. $5 \%$ or the total $\mathrm{Cp}^{*}$ intensity after the addition of 4.3 equiv of $\mathrm{H}_{2} \mathrm{O}$ per $\mathrm{Cp} * \mathrm{~W}$ unit). This behavior is similar to that observed in acetone and this resonance is therefore tentatively assigned to $\left[\mathrm{Cp} * \mathrm{WO}_{2}(\mathrm{OH})\right]$. This result indicates that equilibrium 5 is more heavily shifted toward the left hand side in $\mathrm{CD}_{3} \mathrm{CN}$, like in acetone$d 6$, relative to $\mathrm{CD}_{3} \mathrm{OD}$ and DMSO- $d_{6}$.

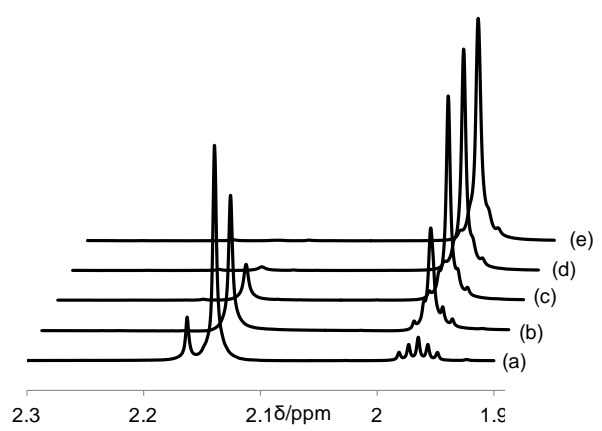

Figure 13. ${ }^{1} \mathrm{H}$ NMR spectra of compound $\left[\mathrm{Cp}_{2}{ }_{2} \mathrm{~W}_{2} \mathrm{O}_{5}\right](10 \mathrm{mg}, 0014 \mathrm{mmol})$ in $\mathrm{CD}_{3} \mathrm{CN}$ (ca. $0.5 \mathrm{~mL}$ ). (a) without additives; $(b)$-(e) after incremental addition of $\mathrm{NEt}_{3}(2 \mathrm{M}$ in $\mathrm{CD}_{3} \mathrm{CN}, 6.5 \mu \mathrm{L}$ or $0.013 \mathrm{mmol}$ for each addition). The residual solvent resonance is visible as a $1: 2: 3: 2: 1$ quintet at $\delta 1.965$.

The water peak also disappears from the $\mathrm{Cp}^{*}$ region upon addition of TFA and $\mathrm{Et}_{3} \mathrm{~N}$. The addition of TFA does not significantly alter the shape of the $\left[\mathrm{Cp}_{2}{ }_{2} \mathrm{~W}_{2} \mathrm{O}_{5}\right]$ resonance, in line with the behavior in the previously examined organic solvents. It is to be noted that, when large amounts of $\mathrm{CF}_{3} \mathrm{COOH}$ were added (up to $32 \mu \mathrm{L}, 0.064 \mathrm{mmol}$ ), additional lower field $\mathrm{Cp}^{*}$ resonances slowly and irreversibly appeared in the spectrum, indicating decomposition. This phenomenon was more evident in this solvent relative to the others described above. However, no sign of decomposition was visible for moderately acidic solutions.

The addition of $\mathrm{Et}_{3} \mathrm{~N}$, besides shifting the water peak away from the $\mathrm{Cp}^{*}$ region, yields a spectral evolution exactly as described above in acetone- $d_{6}$, with the gradual disappearance of the main 
resonance at $\delta 2.139$ and the corresponding increase of the free $\left[\mathrm{Cp} * \mathrm{WO}_{3}\right]^{-}$resonance at $\delta 1.965$, without any chemical shift drift due to the absence of any notable amount of $\left[\mathrm{Cp}^{*} \mathrm{WO}_{2}(\mathrm{OH})\right]$, see spectra $d-g$ in Figure 13. Thus, the water contaminant in the solvent is not sufficient to produce a significant amount of $\left[\mathrm{Cp} * \mathrm{WO}_{2}(\mathrm{OH})\right]$ according to equation 5 but is sufficient to provide the necessary oxido ligand and protons for the amine, according to equation 6 . These spectral changes are reversible, as already found for the studies in the other solvents.

The behavior of the Mo analogue, $\left[\mathrm{Cp}^{*}{ }_{2} \mathrm{Mo}_{2} \mathrm{O}_{5}\right]$, in $\mathrm{CD}_{3} \mathrm{CN}$ is completely equivalent to that of its $\mathrm{W}$ congener, see Figure $\mathrm{S} 6$ in the Supporting Information. The spectrum of isolated $\mathrm{Na}\left[\mathrm{Cp} * \mathrm{MoO}_{3}\right]$ is also quite analogous to that of the $\mathrm{W}$ congener, showing strong ion pairing and slow exchange between the ion-paired and free $\left[\mathrm{Cp} * \mathrm{MoO}_{3}\right]^{-}$ion, respectively evidenced by a major resonance at $\delta$ 2.182 and a small one at $\delta 1.822$. The ratio between the two resonances $(90: 10)$ is very similar to that observed for the W analogue (vide supra). The shift of the resonance of the free $\left[\mathrm{Cp} * \mathrm{MoO}_{3}\right]^{-}$from the $\mathrm{Na}^{+}$salt solution to the solution obtained by adding $\mathrm{NEt}_{3}$ to $\left[\mathrm{Cp}^{*}{ }_{2} \mathrm{Mo}_{2} \mathrm{O}_{5}\right]$ (containing the $\mathrm{Et}_{3} \mathrm{NH}^{+}$salt) is attributed to the weak $\left[\mathrm{Cp}^{*} \mathrm{MoO}_{3}{ }^{-} \cdot \mathrm{HNEt}_{3}{ }^{+}\right]$interaction and is totally consistent with the behavior described above for the corresponding $\mathrm{W}$ compound.

\section{(f) Summary of the ${ }^{1} \mathrm{H}$ NMR investigations}

The combined ${ }^{1} \mathrm{H}$ NMR investigations are in complete agreement with the results of the electrical conductivity studies, in the sense that the dominant or exclusive species in all organic solvents is undissociated $\left[\mathrm{Cp}^{*}{ }_{2} \mathrm{M}_{2} \mathrm{O}_{5}\right]$ (except for the $\mathrm{W}$ derivative in neat $\mathrm{CD}_{3} \mathrm{OD}$ where the extensive formation of a solvent adduct, proposed to be $\left[\mathrm{Cp}^{*} \mathrm{WO}_{2}(\mu-\mathrm{OMe})\right]_{2}$, is suggested). Only in DMSO- $d_{6}$ the presence of water significantly splits the dinuclear compound into the hydroxido monomer, $\left[\mathrm{Cp} * \mathrm{MO}_{2}(\mathrm{OH})\right]$. In the $\mathrm{D}_{2} \mathrm{O}$-rich mixture containing $80 \%$ of $\mathrm{D}_{2} \mathrm{O}$ and $20 \%$ of $\mathrm{CD}_{3} \mathrm{OD}$, on the other hand, extensive dissociation to mononuclear $\left[\mathrm{Cp}^{*} \mathrm{MO}_{2}(\mathrm{OD})\right]$ and ionic dissociation of the latter to yield $\left[\mathrm{Cp} * \mathrm{MO}_{2}\left(\mathrm{D}_{2} \mathrm{O}\right)\right]^{+}$and $\left[\mathrm{Cp} * \mathrm{MO}_{3}\right]$ occurs. All four species may coexist in this medium, but their relative amounts cannot be accurately determined because of fast exchange processes that equilibrate on one side $\left[\mathrm{Cp}^{*} \mathrm{MO}_{2}(\mathrm{OH})\right]$ and $\left[\mathrm{Cp} * \mathrm{MO}_{3}\right]^{-}$and on the other side $\left[\mathrm{Cp} * \mathrm{MO}_{2}\left(\mathrm{D}_{2} \mathrm{O}\right)\right]^{+}$and $\left[\mathrm{Cp}_{2} \mathrm{M}_{2} \mathrm{O}_{5}\right]$ In the organic solvents, addition of $\mathrm{Et}_{3} \mathrm{~N}$, with the help of small amounts of the adventitious water, transforms $\left[\mathrm{Cp}_{2}{ }_{2} \mathrm{M}_{2} \mathrm{O}_{5}\right]$ into $\left[\mathrm{Cp} * \mathrm{MO}_{3}\right]^{-}$. On the other hand, it is unclear whether addition of the strong acid $\mathrm{CF}_{3} \mathrm{COOH}$ generates a significant amount of the solvent stabilized dioxido cation, $\left[\mathrm{Cp} * \mathrm{MO}_{2} \text { (solvent) }\right]^{+}$, because the two species rapidly exchange and their chemical shift may be quite similar. However, on the basis of the weak but non zero electrical conductivity results shown in Table 1, it seems that the generation of this cation is viable.

The resonances of the four different species observed in the various solvents are summarized in Table 2 and are also represented in graphical form in the supporting information (Figure S7). The resonance trends display a certain internal consistency, with the chemical shift moving downfield in the order DMSO- $d_{6}<\mathrm{CD}_{3} \mathrm{CN} \sim$ acetone- $d_{6}<\mathrm{CD}_{3} \mathrm{OD}$ for all species. The total chemical shift span (from DMSO- $d_{6}$ to $\mathrm{CD}_{3} \mathrm{OD}$ ) increases from $\left[\mathrm{Cp}^{*}{ }_{2} \mathrm{M}_{2} \mathrm{O}_{5}\right]$ (Mo: 0.114 ppm; W: $0.136 \mathrm{ppm})$, through $\mathrm{Cp}^{*} \mathrm{MO}_{2}(\mathrm{OH})$ (W: $\left.0.175 \mathrm{ppm}\right)$, to [Cp*MO$]^{-}(\mathrm{Mo}: 0.209 \mathrm{ppm}$; W: $0.207 \mathrm{ppm})$, in an increasing order of molecule-solvent interaction. The values of the $\mathrm{Cp} * \mathrm{Mo}$ resonances are upfield from those of the $\mathrm{Cp} * \mathrm{~W}$ analogue for each species and in each solvent. This includes the neutral compound $\left[\mathrm{Cp}_{2}{ }_{2} \mathrm{M}_{2} \mathrm{O}_{5}\right]$ in $\mathrm{CDCl}_{3}\left(\delta_{\mathrm{w}}-\delta_{\mathrm{Mo}}\right.$ is always in the 0.095-0.166 range). They follow exactly the same trend for the different species as a function of the solvent, as can be most clearly seen in Figure S7.

Table 2. Summary of the chemical shifts for the observed species generated from $\left[\mathrm{Cp}_{2}{ }_{2} \mathrm{M}_{2} \mathrm{O}_{5}\right](\mathrm{M}=\mathrm{Mo}, \mathrm{W})^{[\mathrm{a}]}$ and $\mathrm{Na}^{+}\left[\mathrm{Cp}^{*} \mathrm{WO}_{3}\right]^{-}$in various solvents. ${ }^{[\mathrm{b}]}$

\begin{tabular}{|c|c|c|c|c|c|}
\hline Solvent & {$\left[\mathrm{Cp} * \mathrm{MO}_{2}\left(\mathrm{H}_{2} \mathrm{O}\right)\right]^{+}$} & {$\left[\mathrm{Cp}_{2} \mathrm{M}_{2} \mathrm{O}_{5}\right]$} & {$\left[\mathrm{Cp} * \mathrm{MO}_{2}(\mathrm{OH})\right]$} & {$\left[\mathrm{Cp}^{*} \mathrm{MO}_{3}\right]^{-[\mathrm{c}]}$} & {$\left[\mathrm{Cp} * \mathrm{WO}_{3}\right]^{-[\mathrm{d}]}$} \\
\hline $\begin{array}{l}\mathrm{D}_{2} \mathrm{O}: \mathrm{CD}_{3} \\
\mathrm{OD} \\
(80: 20)\end{array}$ & $2.077 / 2.244$ & - & $2.091 / 2.210$ & $\begin{array}{l}1.942 / 2.06 \\
7\end{array}$ & 2.064 \\
\hline $\mathrm{CD}_{3} \mathrm{OD}$ & - & $\begin{array}{l}2.045 / 2.21 \\
1\end{array}$ & - & $\begin{array}{l}1.938 / 2.06 \\
2\end{array}$ & 2.060 \\
\hline DMSO- $d_{6}$ & - & $\begin{array}{l}1.931 / 2.07 \\
5\end{array}$ & $1.921 / 2.034$ & $\begin{array}{l}1.729 / 1.85 \\
5\end{array}$ & 1.800 \\
\hline $\begin{array}{l}\text { Acetone- } \\
d_{6}\end{array}$ & - & $\begin{array}{l}1.998 / 2.14 \\
1\end{array}$ & n.d. $/ 2.100$ & $\begin{array}{l}1.867 / 1.96 \\
2\end{array}$ & 1.929 \\
\hline $\mathrm{CD}_{3} \mathrm{CN}$ & - & $\begin{array}{l}1.994 / 2.13 \\
9\end{array}$ & n.d./2.116 & $\begin{array}{l}1.862 / 1.96 \\
5\end{array}$ & $1.936^{\text {ee] }}$ \\
\hline $\mathrm{CDCl}_{3}$ & - & $\begin{array}{l}2.048 / 2.18 \\
0\end{array}$ & - & - & - \\
\hline
\end{tabular}

[a] Left value, Mo; right value, W. [b] n.d. = not determined. [c] From $\left[\mathrm{Cp}_{2}{ }_{2} \mathrm{M}_{2} \mathrm{O}_{5}\right] / \mathrm{Et}_{3} \mathrm{~N}$. [d] From $\mathrm{Na}\left[\mathrm{Cp} * \mathrm{WO}_{3}\right]$. [e] Corresponding value for $\left[\mathrm{Cp} * \mathrm{MoO}_{3}\right]^{-}=$ 1.822 .

\section{Computational studies}

Taking into account the above experimental data, DFT calculations were performed to confirm and further refine the understanding of the speciation of $\left[\mathrm{Cp}_{2}{ }_{2} \mathrm{M}_{2} \mathrm{O}_{5}\right](\mathrm{M}=\mathrm{Mo}$ or $\mathrm{W})$ in different protic and aprotic polar solvents, on the basis of Scheme 1, Scheme 2 and Scheme 3. Within the discussion of the computational results, the dinuclear compounds $\left[\mathrm{Cp}_{2}{ }_{2} \mathrm{M}_{2} \mathrm{O}_{5}\right]$ are symbolized as $\mathbf{D}$ (DMo and $\mathbf{D}_{\mathbf{W}}$ depending on the metal nature), the anions $\left[\mathrm{Cp}^{*} \mathrm{MoO}_{3}\right]^{-}$are called $\mathbf{A}$ ( $\mathbf{A}_{\mathbf{M o}}$ and $\mathbf{A}_{\mathbf{W}}$ ) and the cations $\left[\mathrm{Cp}^{*} \mathrm{MO}_{2}\right]^{+}$are called $\mathbf{C}$ $\left(\mathbf{C}_{\mathbf{M}}\right.$ and $\left.\mathbf{C}_{\mathbf{w}}\right)$. The theoretical study is mainly divided in three sections. The first section concerns the study of the complete ionic dissociation of $\left[\mathrm{Cp}_{2}{ }_{2} \mathrm{M}_{2} \mathrm{O}_{5}\right]$ leading to the formation of $\mathbf{A}$ and $\mathbf{C}$. In the subsequent section, we computationally analyze the explicit participation of water molecules in the split reaction of D. Finally, the last part examines the effect of the addition of methanol to $\left[\mathrm{Cp}_{2}{ }_{2} \mathrm{M}_{2} \mathrm{O}_{5}\right]$. In order to check the adequacy of the used theory level for the study of the nature of $\mathbf{D}$ in different solvents, we have compared the optimized structure of both dimeric compounds with the X-ray crystal structures of these compounds. ${ }^{[3 f, 13]}$ A view of the D structure is available in Figure 14 and the key geometrical parameters are summarized in Table 3.

A remarkable good agreement is observed between the experimental and DFT optimized structures. In particular, all important calculated $\mathrm{M}-\mathrm{O}$ bond distances (including those involving the $\mathrm{O}_{\mu}$ atom) follow the same trends as in the experimentally determined structures. Likewise, the different considered angles are in good agreement. Thus, the used level of theory is adequate to the study of these different molecular systems. However, it is noteworthy that the use of hybrid M06 functional which includes dispersion corrections leads to a better agreement of the $\mathrm{M}_{1}-\mathrm{O}_{\mu}-\mathrm{M}_{2}$ angle than the use of B3PW91. Therefore, for the sake of clarity, only the results of the M06 calculations are presented for the remainder of this contribution.

The geometries of $\mathbf{D}_{\mathbf{M} o}$ and $\mathbf{D}_{\mathbf{W}}$ have also been optimized in each solvent polarizable continuum model and the results are shown in table S1. The structure is little affected except for methanol and 
water, which significantly elongate the $\mathrm{M}=\mathrm{O}$ and $\mathrm{M}-\mathrm{O}_{\mu}$ distances (by up to $0.02 \AA$ ). The natural charges of the different atoms (see Table S2) are essentially identical in the three aprotic solvents (acetone, $\mathrm{MeCN}$ and $\mathrm{DMSO}$ ), but on going to $\mathrm{MeOH}$ and water the metal charge becomes more positive (by ca. +0.20 for Mo and +0.25 for $\mathrm{W}$ ) and the terminal $\mathrm{O}$ atoms charge becomes more negative (by ca. -0.1), whereas the natural charge on the $\mathrm{O}_{\mu}$ atom does not change. As discussed below, the same effect is found when additional water molecules involved in hydrogen bonds with the $\mathrm{M}=\mathrm{O}$ bonds are included in the calculations. This result points out that a purely continuum solvent description is able to take into account the main part of the electrostatic contribution to the hydrogen-bond interaction. ${ }^{[14]}$ All the energetic data discussed in the following sections include the solvation correction and refer to molecules or ions optimized in the appropriate solvent model.
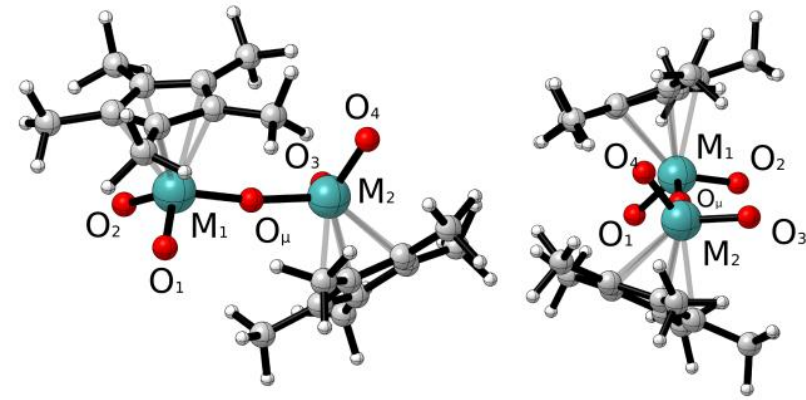

Figure 14. Two orthogonal views of the $\left[\mathrm{Cp}_{2}{ }_{2} \mathrm{M}_{2} \mathrm{O}_{5}\right](\mathrm{M}=\mathrm{Mo}$ or $\mathrm{W})$ structure. The molecule shown is with $\mathrm{M}=\mathrm{Mo}$. The other complex adopts an identical conformation.

Table 3. Comparison between the experimental and DFT optimized (gas phase B3PW91 and, in brackets, M06 calculations) geometries of $\left[\mathrm{Cp}^{*}{ }_{2} \mathrm{M}_{2} \mathrm{O}_{5}\right](\mathrm{M}=\mathrm{Mo}$ or $\mathrm{W})$ complexes for selected metric parameters.

\begin{tabular}{|c|c|c|c|c|}
\hline & \multicolumn{2}{|c|}{ Molybdenum } & \multicolumn{2}{|l|}{ Tungsten } \\
\hline & X-Ray ${ }^{[a]}$ & DFT & X-Ray ${ }^{[b]}$ & DFT \\
\hline $\begin{array}{l}\text { Distances }(\AA) \\
\text { d(M1-O1) }\end{array}$ & $1.701(7)$ & $1.710(1.708)$ & $1.732(7)$ & $\begin{array}{l}1.730 \\
(1.727)\end{array}$ \\
\hline $\mathrm{d}(\mathrm{M} 1-\mathrm{O} 2)$ & $1.701(7)$ & 1.703 (1.697) & $1.711(7)$ & $\begin{array}{l}1.724 \\
(1.719)\end{array}$ \\
\hline $\mathrm{d}(\mathrm{M} 1-\mathrm{O} \mu)$ & $1.889(6)$ & $1.896(1.895)$ & $1.892(6)$ & $\begin{array}{l}1.902 \\
(1.899)\end{array}$ \\
\hline d(M2-O3) & $1.689(7)$ & 1.703 (1.696) & $1.729(6)$ & $\begin{array}{l}1.724 \\
(1.719)\end{array}$ \\
\hline d(M2-O4) & $1.689(7)$ & $1.711(1.708)$ & $1.727(6)$ & $\begin{array}{l}1.732 \\
(1.728)\end{array}$ \\
\hline $\mathrm{d}(\mathrm{M} 2-\mathrm{O} \mu)$ & $1.855(6)$ & $1.894(1.893)$ & $1.881(6)$ & $\begin{array}{l}1.900 \\
(1.899)\end{array}$ \\
\hline \multicolumn{5}{|l|}{ Angles $\left({ }^{\circ}\right)$} \\
\hline O1-M1-O $\mu$ & 105.3(3) & $105.2(105.9)$ & $104.2(3)$ & $\begin{array}{l}104.6 \\
(105.3)\end{array}$ \\
\hline $\mathrm{O} 2-\mathrm{M} 1-\mathrm{O} \mu$ & $105.9(3)$ & $106.4(107.1)$ & $105.7(3)$ & $\begin{array}{l}105.6 \\
(106.2)\end{array}$ \\
\hline M1-O $\mu-\mathrm{M} 2$ & 179.2(4) & $166.3(176.2)$ & $170.1(4)$ & $\begin{array}{l}169.7 \\
(174.7)\end{array}$ \\
\hline $\mathrm{O} 3-\mathrm{M} 2-\mathrm{O} \mu$ & 106.1(3) & $106.7(106.8)$ & $104.6(3)$ & $\begin{array}{l}105.9 \\
(106.3)\end{array}$ \\
\hline $\mathrm{O} 4-\mathrm{M} 2-\mathrm{O} \mu$ & $105.1(3)$ & $105.2(106.0)$ & $105.5(3)$ & $104.6(105.2)$ \\
\hline
\end{tabular}

[a] Ref. [13]. [b] Ref. [3f].

\section{(a) Ionic dissociation equilibrium}

As experimentally shown, the heterolytic cleavage of an $\mathrm{M}-\mathrm{O}_{\mu}$ bond of $\mathbf{D}$ takes place more or less extensively in polar solvents according to equation 1 . This reaction may be formally viewed as a two-step process, the first one being ionization to generate $\mathbf{C}$ and $\mathbf{A}$, followed by solvent coordination to the cation to generate $\mathbf{C}$-solv. The coordinative bond is established through the donation from a lone pair of the oxygen atom (acetone and DMSO) or the nitrogen atom (acetonitrile) to an empty orbital of $\mathbf{C}$. When the solvent is also protic (water, methanol), additional hydrogen bonding interactions may contribute to stabilize both the cation and the anion As a result, the ions are solvated and surrounded by a solvent shell in protic polar solvents. For the purpose of the present study, we have explicitly added the second coordination sphere for both cation and anion but only for water. For the cation, the solvation was first restricted to the establishment of the coordinative bond, C-solv, followed by the addition of four additional explicit water molecules, $\mathbf{C} \cdot \mathbf{4} \mathbf{H}_{2} \mathrm{O}$. For the anion, we have added one solvent molecule $\mathrm{H}-$ bonded to two of the three oxygen atoms, $\mathbf{A} \cdot \mathbf{2} \mathbf{H}_{2} \mathbf{O}$, or to each oxygen atom, $\mathbf{A} \cdot \mathbf{3} \mathbf{H}_{2} \mathbf{O}$ (see Scheme 5). The solvation effects, however, are included for all ions by optimization in the solvent polarizable continuum model.
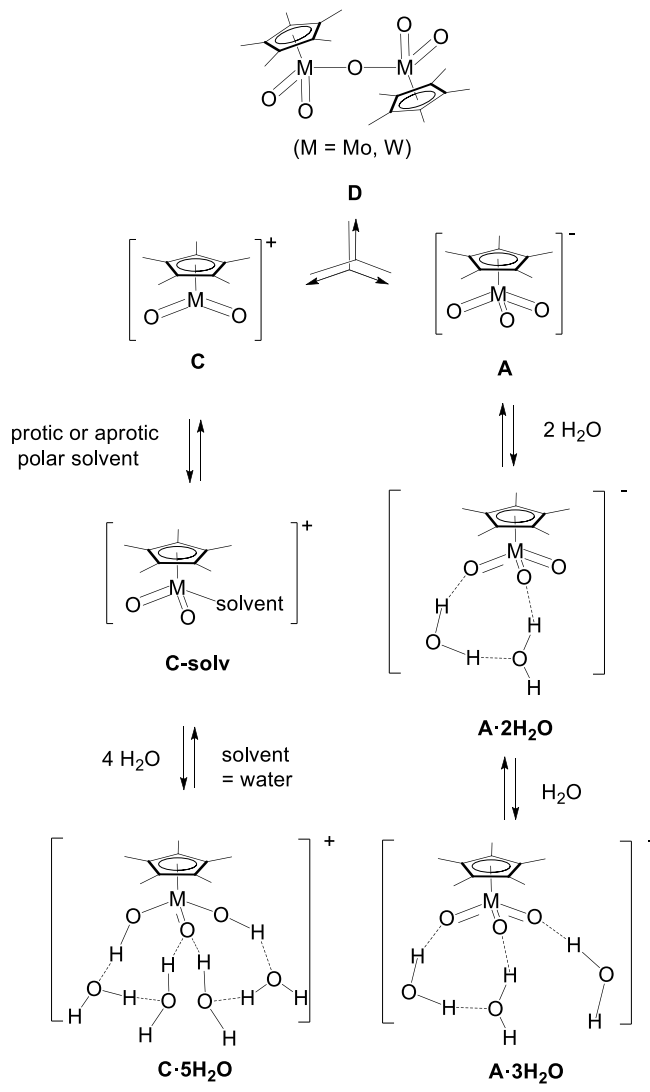

Scheme 5. Schematic representation of the dissociation reaction of D and of the solvation reaction of the formed ions in protic or aprotic polar solvents.

The structures of A, $\mathbf{C}$ and $\mathbf{C}$-solv (optimized parameters collected in Table S3), like those of $\mathbf{D}$, are little affected by the solvent polarizable continuum model in the aprotic solvents. On the other hand, the $\mathrm{M}=\mathrm{O}$ bonds for the anion $\mathbf{A}$ on going to $\mathrm{MeOH}$ and $\mathrm{H}_{2} \mathrm{O}$ are elongated, again by ca. $0.02 \AA$ as for $\mathbf{D}$, whereas those of $\mathbf{C}$ and $\mathbf{C}$-solv remain relatively unaffected.

The Gibbs energies of the ionic dissociation reaction of $\mathbf{D}$ in polar solvents are given in Table 4 . The dissociation to $\mathbf{A}$ and $\mathbf{C}$ solv is always endergonic, the $\Delta \mathrm{G}$ values for $\mathbf{D}_{\mathbf{M} o}$ and $\mathbf{D}_{\mathbf{W}}$ being quite similar in each solvent. The small difference is mostly related to differences in the ionization step in DMSO, to differences in the 
solvent coordination step in acetonitrile, and to both steps in acetone. In water and methanol, both steps are also affected by the metal nature but the trends are opposite resulting in partial compensation. The cost of the ionization step is always marginally greater for $\mathbf{D}_{\mathbf{w}}$ and smaller for $\mathbf{D}_{\mathbf{M o}}$ (by as little as $0.2 \mathrm{kcal} / \mathrm{mol}$ in $\mathrm{MeCN}$ and as much as $4.2 \mathrm{kcal} / \mathrm{mol}$ in acetone and water). The influence of the solvent nature on the easiness of the ionic dissociation is apparent from the values in Table 4. Polar protic solvents (methanol and water) give Gibbs energies for the ionic dissociation much lower than polar aprotic solvents (acetone, acetonitrile and DMSO). This behavior, which deviates from that expected from the variation of solvent dielectric constant, could be related to the anion stabilization by means of a hydrogen bonding network with the solvent molecules of the polar protic solvents. As discussed above, the main part of the electrostatic contribution to the hydrogen bond interaction is taken into account by a continuum model of the solvent. The cation solvation step is in all cases thermodynamically favorable, with DMSO being by far the best donor as expected, followed by water and the other three solvents. The energy gain for this step is very similar for Mo and $\mathrm{W}$ in DMSO and $\mathrm{MeOH}$, whereas acetone and $\mathrm{MeCN}$ coordinate slightly more strongly to Mo and water binds better to $\mathrm{W}$. Given the Lewis acidic nature of $\mathbf{D}$, it is perhaps surprising that $\mathrm{MeOH}$ binds less strongly than water. However, coordination is relatively weak in all cases and the related stabilization does not overcome the cost of the ionization step. The endergonicity is much reduced in water $\left(13.6\right.$ and $14.7 \mathrm{kcal} \cdot \mathrm{mol}^{-1}$ respectively, for $\mathbf{D}_{\mathbf{M o}}$ and $\left.\mathbf{D w}\right)$, namely ca. $20 \mathrm{kcal} \cdot \mathrm{mol}^{-1}$ less than in acetone or acetonitrile and ca. $10 \mathrm{kcal} \cdot \mathrm{mol}^{-1}$ less than in DMSO and $\mathrm{MeOH}$. This is mostly due to the lower cost of the ion separation step, resulting from the water high dielectric constant $(\varepsilon=80.1$, vs. 46.7 for DMSO).

Table 4. Comparison of the D ionic dissociation Gibbs energy (in $\mathrm{kcal} \cdot \mathrm{mol}^{-1}$ ) in different polar solvents.

\begin{tabular}{|c|c|c|c|c|c|c|}
\hline \multirow[b]{2}{*}{ Solvent } & \multicolumn{2}{|c|}{$D \rightleftharpoons C+A$} & \multicolumn{2}{|c|}{$\begin{array}{l}\mathrm{C}+\text { solv }=\mathrm{C}- \\
\text { solv }\end{array}$} & \multicolumn{2}{|c|}{$\begin{array}{l}\text { D + solv }=\text { C-solv }+ \\
\text { A }\end{array}$} \\
\hline & $\mathbf{D}_{\mathrm{Mo}}$ & $\mathbf{D}_{\mathrm{w}}$ & $\mathbf{D}_{\mathrm{Mo}}$ & $\mathbf{D}_{\mathbf{W}}$ & $\mathbf{D}_{\mathrm{Mo}}$ & $\mathbf{D}_{\mathrm{w}}$ \\
\hline Acetone & 41.6 & 45.8 & -6.3 & -3.7 & 35.3 & 42.1 \\
\hline Acetonitrile & 36.4 & 36.6 & -3.2 & -1.0 & 33.2 & 35.6 \\
\hline DMSO & 41.3 & 42.7 & -18.3 & -18.0 & 23.0 & 24.7 \\
\hline Methanol & 26.9 & 30.9 & -3.1 & -3.8 & 23.8 & 27.1 \\
\hline Water & 20.8 & 25.0 & -7.2 & -10.3 & 13.6 & 14.7 \\
\hline
\end{tabular}

Whereas the results in Table 4 agree with the lack of ionic dissociation of $\mathbf{D}$ in the less dielectric solvents, it disagrees with the observed extensive dissociation in water as experimentally proven by the conductivity studies. In order to improve the model, we have therefore explicitly included four and seven water molecules per dimer, $\mathrm{D} \cdot \mathbf{4} \mathrm{H}_{2} \mathrm{O}$ and $\mathrm{D} \cdot \mathbf{7} \mathrm{H}_{2} \mathrm{O}$ respectively. For $\mathrm{D} \cdot \mathbf{4} \mathrm{H}_{2} \mathrm{O}$, one of the four water molecules is used for coordination to $\mathbf{C}$ to generate $\mathbf{C}$ solv and the other three are used to establish $\mathrm{H}$ bonds to the three oxygen atoms of $\mathbf{A}$ to generate $\mathbf{A} \cdot \mathbf{3} \mathbf{H}_{2} \mathbf{O}$. The optimized structures are shown in Figure S8 and the key geometrical parameters for D. $4 \mathrm{H}_{2} \mathrm{O}$ and $\mathbf{A} \cdot \mathbf{3} \mathrm{H}_{2} \mathrm{O}$ are gathered in Table S4 and Table S3, respectively. The $\mathrm{M}=\mathrm{O}$ distances are further elongated (by $0.01-0.02$ $\AA$ ) on going from $\mathrm{D}$ to $\mathbf{D} \cdot \mathbf{4} \mathrm{H}_{2} \mathrm{O}$ and from $\mathrm{A}$ to $\mathbf{A} \cdot \mathbf{3} \mathrm{H}_{2} \mathrm{O}$ because they are directly involved in the $\mathrm{H}$ bonds with the additional water molecules, whereas the $\mathrm{M}-\mathrm{O}_{\mu}$ bonds slightly shorten. The greater strength of the $\mathrm{H}$-bonds established by water with the anionic compounds relative to the dinuclear precursor significantly lowers the cost of the ionization process, which remains however slightly endergonic (Gibbs energies of $+4.7 \mathrm{kcal}^{\mathrm{mol}}{ }^{-1}$ for both metals). For D. $7 \mathbf{H}_{2} \mathrm{O}$, four additional water molecules are added to $\mathbf{C}$-solv to generate $\mathbf{C} \cdot \mathbf{5} \mathbf{H}_{2} \mathrm{O}$ and the other two are used to establish $\mathrm{H}$ bonds to the two of the three oxygen atoms of $\mathbf{A}$ leading to $\mathbf{A} \cdot \mathbf{2} \mathbf{H}_{2} \mathrm{O}$. The optimized structures are shown in Figure S8 and the key geometrical parameters for $\mathbf{D} \cdot \mathbf{7} \mathbf{H}_{2} \mathrm{O}, \mathbf{C} \cdot \mathbf{5} \mathbf{H}_{2} \mathrm{O}$ and $\mathbf{A} \cdot \mathbf{2} \mathrm{H}_{2} \mathrm{O}$ are gathered in Table $\mathrm{S} 4$ and Table S3. The inclusion of three additional explicit water molecules follows the same trends observed with $\mathbf{D} \cdot \mathbf{4} \mathbf{H}_{\mathbf{2}} \mathrm{O}$, i.e., an elongation of the $\mathrm{M}=\mathrm{O}$ distances and a slight shortening of the $\mathrm{M}-\mathrm{O}_{\mu}$ bonds. The inclusion of three additional water molecules further lowers the cost of the ionization process (Gibbs energies of +2.2 and $+2.0 \mathrm{kcal}^{\mathrm{mol}} \mathrm{l}^{-1}$ respectively for Mo and W). We can then extrapolate than the inclusion of additional water molecules will lead to an exergonic process in agreement with the experiment.

We have also briefly investigated the formation of the trinuclear $\left[\mathrm{Cp}_{2}{ }_{2} \mathrm{M}_{3} \mathrm{O}_{7}\right]^{+}$cations $(\mathrm{M}=\mathrm{Mo}$ or $\mathrm{W}$ ), which has been proposed to be implicated as an intermediate in the rapid exchange between the neutral dinuclear system and the cation as indicated in Scheme 2. A view of the $\left[\mathrm{Cp}^{*}{ }_{2} \mathrm{M}_{3} \mathrm{O}_{7}\right]^{+}$cation structures is available in Figure 15 and the key geometrical parameters are summarized in Table S5. The trinuclear cations are a local energy minimum on the potential energy surface, very close in energy to the reactant compounds $\mathbf{D}+$ C $\left(-3.7 \mathrm{kcal} . \mathrm{mol}^{-1}\right.$ for Mo and $-0.9 \mathrm{kcal}^{\mathrm{mol}}{ }^{-1}$ for $\left.\mathrm{W}\right)$. Note that calculated energy change associated to this process, like in the previously examined ionic dissociation of $\mathbf{D}$, could be tuned by the number of water molecules explicitly included in the calculation. Although the activation barrier for the formation of these trinuclear species was not investigated, the very low energy involved in the association process agrees with the experimental observation of this ion (for Mo) under mild conditions ${ }^{[11]}$ and comforts the proposition that it is the intermediate of the observed rapid exchange between the neutral dinuclear systems and the cations.

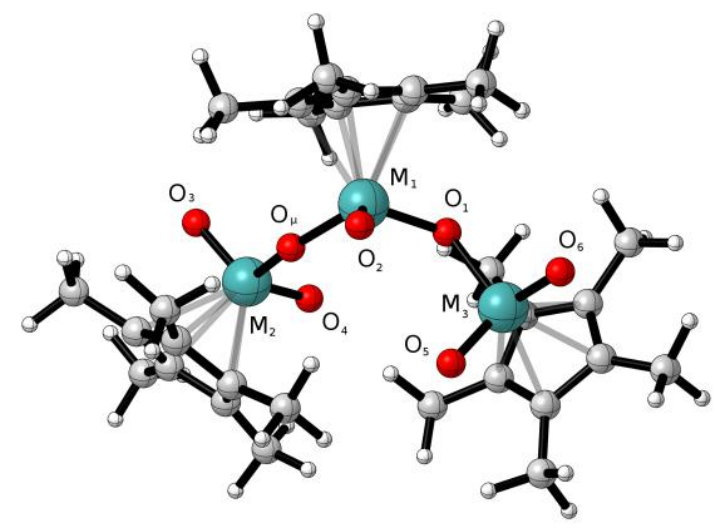

Figure 15. Optimized geometry of $\left[\mathrm{Cp}_{2}{ }_{2} \mathrm{Mo}_{2} \mathrm{O}_{7}\right]^{+}$. The tungsten complex adopts an identical conformation and is not represented.

\section{(b) Dimer splitting by water}

In this section, we examine the splitting reaction of $\mathbf{D}$ by water, yielding the neutral mononuclear hydroxido $\left[\mathrm{Cp}^{*} \mathrm{MO}_{2}(\mathrm{OH})\right](\mathbf{N})$. This reaction, shown in equation 5 (for $\mathrm{D}_{2} \mathrm{O}$ ), was shown by the NMR investigations to proceed more extensively in $\mathrm{CD}_{3} \mathrm{OD}$ and DMSO and less extensively in acetone and MeCN. Like for the ionic dissociation reaction, two scenarios were considered, the first one with the addition of only one water molecule to $\mathbf{D}$ in order to simulate the presence of small quantities of water (or residual water) in the polar aprotic solvents and the second one starting from D. $4 \mathrm{H}_{2} \mathrm{O}$, in which case the mononuclear hydroxido compound $\mathbf{N}$ was also considered as a water solvate, $\mathbf{N} \cdot \mathbf{2} \mathbf{H}_{2} \mathbf{O}$. Optimized structures of $\mathbf{N}$ and $\mathbf{N} \cdot 2 \mathrm{H}_{2} \mathrm{O}$ are shown in Figure 16 and the key 
geometrical parameters are collected in Table S6, whereas Table S7 lists the key parameters of $\mathbf{D} \cdot \mathbf{4} \mathbf{H}_{2} \mathrm{O}$ optimized in the various polar solvents. From the structural point of view, as can be seen in tables S6 and S7, the geometries of the different compounds are nearly insensitive to the nature of the polar solvent.

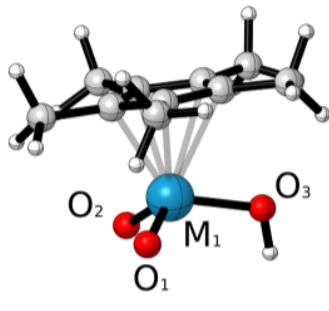

$\mathrm{N}$

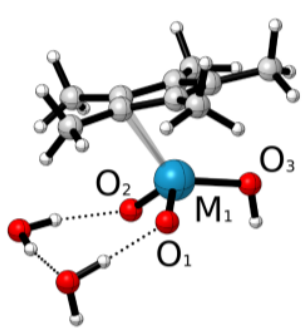

$\mathrm{N} \cdot 2 \mathrm{H}_{2} \mathrm{O}$
Figure 16. Optimized geometries of $\mathrm{N}$ and $\mathrm{N} \cdot 2 \mathrm{H}_{2} \mathrm{O}$ complexes in water $(\mathrm{M}=\mathrm{Mo})$. The optimized geometries of the $\mathrm{W}$ complexes as well as those in the other solvents for both metals are similar and are not represented.

The resulting reaction Gibbs energies are gathered in Table 5. The splitting reaction of $\mathbf{D}$ is only slightly endergonic for both metals in the different polar aprotic solvents. The explicit addition of water molecules leads to a more favorable reaction, becoming essentially athermic for both $\mathbf{D}_{\mathbf{M o}} \cdot \mathbf{4 H}_{\mathbf{2}} \mathrm{O}$ and $\mathbf{D}_{\mathbf{W}} \cdot \mathbf{4} \mathbf{H}_{2} \mathrm{O}$ with Gibbs energies between -0.5 and $2.0 \mathrm{kcal} . \mathrm{mol}^{-1}$. In water, starting from either $\mathrm{D}$ or $\mathrm{D} \cdot \mathbf{4} \mathrm{H}_{2} \mathrm{O}$, the splitting of the dinuclear complex is an exergonic process $\left(-1.6 \mathrm{kcal} \cdot \mathrm{mol}^{-1}\right.$ for both $\mathbf{D}_{\mathbf{M o}}$ and $\mathbf{D}_{\mathbf{W}} ;-4.4$ and $3.8 \mathrm{kcal} \cdot \mathrm{mol}^{-1}$ for $\mathbf{D}_{\mathbf{M o}} \cdot \mathbf{4} \mathbf{H}_{2} \mathbf{O}$ and $\left.\mathbf{D}_{\mathbf{W}} \cdot \mathbf{4} \mathbf{H}_{2} \mathbf{O}\right)$. Like for the ionic dissociation, the higher dielectric constant of water and the deformation of the dinuclear solvated compounds lead to a more thermodynamically favorable reaction in a water rich environment, although the difference between water and the other solvents is lower in this case, since the reaction is not accompanied by charge separation. The difference between the splitting reaction from $\mathbf{D}$ and $\mathrm{D} \cdot \mathbf{4} \mathrm{H}_{2} \mathrm{O}$ is also lower relative to the ionic dissociation process. This is related to the smaller gain of $\mathrm{H}$-bonding stabilization on going from $\mathrm{D} \cdot \mathbf{4} \mathrm{H}_{2} \mathrm{O}$ to $\mathbf{N} \cdot \mathbf{2} \mathrm{H}_{2} \mathrm{O}$, relative to the process converting D. $4 \mathrm{H}_{2} \mathrm{O}$ into $\mathrm{C}-\mathrm{H}_{2} \mathrm{O}$ and $\mathbf{A} \cdot \mathbf{3} \mathrm{H}_{2} \mathrm{O}$.

Table 5. Comparison of the Gibbs energy (in $\mathrm{kcal} \cdot \mathrm{mol}^{-1}$ ) of the $\mathrm{Cp}^{*} \mathrm{MO}_{2}(\mathrm{OH})$ formation reaction from $\left[\mathrm{Cp}_{2}{ }_{2} \mathrm{M}_{2} \mathrm{O}_{5}\right]$ in different solvents.

\begin{tabular}{|c|c|c|c|c|}
\hline \multirow[b]{2}{*}{ Solvent } & \multicolumn{2}{|c|}{$\mathbf{D}+\mathrm{H}_{2} \mathrm{O} \rightleftharpoons 2 \mathrm{~N}$} & \multicolumn{2}{|c|}{$\mathrm{D} \cdot 4 \mathrm{H}_{2} \mathrm{O}+\mathrm{H}_{2} \mathrm{O} \rightleftharpoons 2 \mathrm{~N} \cdot 2 \mathrm{H}_{2} \mathrm{O}$} \\
\hline & $\mathbf{D}_{\text {Mo }}$ & $\mathbf{D}_{\mathbf{W}}$ & $\mathbf{D}_{\mathrm{Mo}}$ & $\mathbf{D}_{\mathbf{W}}$ \\
\hline Acetone & 3.1 & 2.8 & 1.7 & 1.5 \\
\hline Acetonitrile & 3.4 & 1.8 & 1.1 & 0.6 \\
\hline DMSO & 2.8 & 4.5 & 2.3 & 2.0 \\
\hline Methanol & 0.8 & -0.1 & -3.6 & -0.5 \\
\hline Water & -1.6 & -1.6 & -4.4 & -3.8 \\
\hline
\end{tabular}

The results shown in Table 5 are only in partial agreement with the experimental evidence. The low values of the Gibbs energies agree with the experimental observation of the dimer splitting reaction in all solvents and therefore validate the proposed assignment of the observed NMR resonance generated in the presence of excess water to the neutral hydroxido derivative. On the other hand, the trend of relative extent of dimer splitting as a function of solvent is not completely reproduced by the calculations. In agreement with the experiment, the reaction is computed as most favourable in water and in methanol. However, amongst the other three solvents and for both metals, the reaction is experimentally shown to be most favorable in DMSO and less in MeCN and

acetone, whereas the computed Gibbs energies values would predict the opposite trend. One possible reason for this discrepancy is the possibility that the product $\mathbf{N}$ is further stabilized by $\mathrm{H}$ bonding with DMSO, with involvement of the hydroxido ligand as proton donor, since DMSO is a much stronger proton acceptor in H-bonding than acetone or MeCN. ${ }^{[15]}$

\section{(c) $\mathrm{MeOH}$ addition to $\left[\mathrm{Cp}_{2} \mathrm{M}_{2} \mathrm{O}_{5}\right]$}

In this final section of computational results, we examine the nature of the putative methoxido species that is obtained specifically for the tungsten system when dissolving compound $\mathbf{D}_{\mathbf{w}}$ in neat methanol. The two hypotheses formulated on the basis of the experimental results (see Scheme 3) are a mononuclear neutral species $\left[\mathrm{Cp} * \mathrm{MO}_{2}(\mathrm{OMe})\right]$ (symbolized as $\mathbf{N}-\mathbf{O M e}$ ) or its corresponding dimer $\left[\mathrm{Cp}^{*} \mathrm{MO}_{2}(\mathrm{OMe})\right]_{2}$ (ND-OMe). The geometries of these complexes have been optimized for both metals and are presented in Figure 17. The optimizations were performed in $\mathrm{MeOH}$ but also in water, to evaluate the effect of methanol addition in a water-rich environment. Selected bonding parameters of the optimized geometries for both systems are collected in Table S8.

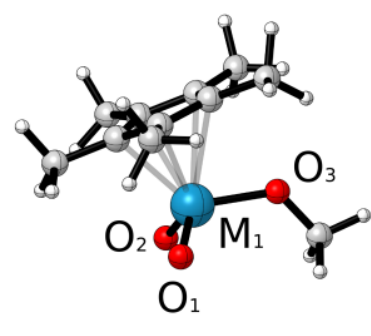

$\mathrm{N}-\mathrm{OMe}$

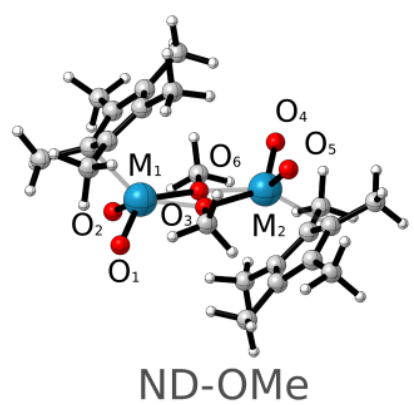

Figure 17. Optimized geometries of the monomeric (N-OMe) and dimeric (ND-OMe) neutral methoxido complexes $\left[\mathrm{Cp}^{*} \mathrm{MO}_{2}(\mathrm{OMe})\right]_{\mathrm{x}}(\mathrm{x}=1$ or 2$)$. The geometries shown are for $\mathrm{M}=\mathrm{Mo}$. The tungsten analogues adopt similar conformations.

The first analyzed reaction is the splitting of the dinuclear compound $\mathbf{D}$ by two molecules of $\mathrm{MeOH}$, affording two molecules of N-OMe and one molecule of water (see the resulting Gibbs energy values in Table 6). As may have been expected, the energy changes of this reaction are rather close to those of the related dinuclear compound splitting by water to yield the hydroxido system $\mathbf{N}$ (Table 5). This process is essentially thermoneutral for both metals, indicating the legitimacy of the assignment of the mononuclear structure N-OMe to the observed product. However, the computed energy change is essentially identical for both metals (slightly more exergonic for Mo), whereas from the experimental point of view, the formation of a new product is observed only for tungsten. A second reaction, related to the first one and to the dinuclear compound splitting by water, is the solvent metathesis leading from $\mathbf{N}$ and $\mathrm{MeOH}$ to $\mathbf{N}-\mathbf{O M e}$ and $\mathrm{H}_{2} \mathrm{O}$. This reaction is also essentially thermoneutral for both metals, both in $\mathrm{MeOH}$ and in water. Going from $\mathrm{MeOH}$ to water slightly favors the formation of $\mathbf{N}$, which agrees with the experimental evidence. Finally, the formation of the dimer ND-OMe was considered. However, the optimized geometry obtained for this compound is highly distorted, with an $\eta^{1}$ coordination of the $\mathrm{Cp}^{*}$ ligand, and corresponds to a rather high energy local minimum. Although the dimerization process is, as predicted, less energy costly for $\mathrm{W}$ relative to Mo, it still remains a very unfavorable process for both metals and leads to 
the conclusion that this structure is unlikely for the methanol addition product.

Table 6. Comparison of the D ionic dissociation Gibbs energy (in $\mathrm{kcal} \cdot \mathrm{mol}^{-1}$ ) in different polar solvents.

\begin{tabular}{|c|c|c|c|c|c|c|}
\hline \multirow[b]{2}{*}{ Solvent } & \multicolumn{2}{|c|}{$\begin{array}{l}\mathbf{D}+2 \mathrm{CH}_{3} \mathrm{OH}= \\
2 \mathrm{~N}-\mathrm{OMe}+\mathrm{H}_{2} \mathrm{O}\end{array}$} & \multicolumn{2}{|c|}{$\begin{array}{l}\mathbf{N}+\mathrm{CH}_{3} \mathrm{OH}= \\
\mathbf{N}-\mathrm{OMe}+\mathrm{H}_{2} \mathrm{O}\end{array}$} & \multirow{2}{*}{$\begin{array}{c}2 \text { N-OMe } \\
\text { D }_{\text {Mo }}\end{array}$} & \multirow{2}{*}{$\begin{array}{c}\text { ND-OMe } \\
\text { D }_{W}\end{array}$} \\
\hline & $\mathbf{D}_{\mathrm{Mo}}$ & $\mathbf{D}_{\mathbf{w}}$ & $\mathbf{D}_{\mathbf{M o}}$ & $\mathbf{D}_{W}$ & & \\
\hline Methanol & -0.5 & -0.1 & $\begin{array}{l}-0.7 \\
\end{array}$ & 0.0 & 12.0 & 11.3 \\
\hline Water & -0.9 & -0.1 & 0.4 & 0.7 & 27.5 & 23.5 \\
\hline
\end{tabular}

In conclusion, this computational investigation suggests that the main product resulting from the dissolution of $\mathbf{D}_{\mathbf{w}}$ in neat methanol (Figure 5) is not the dinuclear compound ND-OMe. Rather, the mononuclear formulation N-OMe remains a likely possibility. However, as pointed out above, the calculation also indicates that the same reaction should also take place for $\mathbf{D}_{\mathbf{M}}$, whereas no equivalent NMR resonance was observed in that case (Figure 3). One possibility to rationalize this discrepancy is the different action, at the quantitative level, of specific solvent interactions (notably $\mathrm{H}$ bonding with external $\mathrm{MeOH}$ molecules, which was neglected in our calculations), for the two metal systems. Another possibility is that the reaction is equally taking place for the two metals, but with a much greater rate for the Mo system resulting in resonance coalescence. This hypothesis, however, seems in contradiction with a slow process for the dinuclear compound splitting by water leading to the observation of both resonances (Figure S2).

\section{Conclusion}

A much greater understanding of the solution behavior of complexes $\left[\mathrm{Cp}{ }_{2} \mathrm{M}_{2} \mathrm{O}_{5}\right]$ in polar coordinating solvents than previously available has been achieved with the present study. While the compounds remain in the oxido-bridged dinuclear form, also adopted in the solid state, ${ }^{[3 f, 13]}$ when dissolved in non coordinating solvents, polar solvents may in principle favor the ionic dissociation to $\left[\mathrm{Cp} * \mathrm{MO}_{2}(\mathrm{~S})\right]^{+}$and $\left[\mathrm{Cp}^{*} \mathrm{MO}_{3}\right]^{-}$by stabilization of the cation through coordination and especially, as shown by the DFT study, by charge separation in a high dielectric medium and hydrogen bonding in a protic solvent, particularly to the anion. Water, while not the strongest donor in the series of solvents investigated, optimizes the latter two effects and provides the strongest ionic dissociation (4:1 $\mathrm{H}_{2} \mathrm{O}-\mathrm{MeOH}$, since the system is insoluble in pure water), whereas the phenomenon remains very limited in the other polar solvents including neat methanol.

The dimer splitting reaction by $\mathrm{ROH}(\mathrm{R}=\mathrm{H}, \mathrm{Me})$ to yield $\left[\mathrm{Cp} * \mathrm{MO}_{2}(\mathrm{OR})\right]$ is also shown to take place, more or less extensively depending on $\mathrm{R}$, on the metal and on the solvent. For $\mathrm{R}=\mathrm{H}$, formation of the neutral hydroxido derivative $\left[\mathrm{Cp} * \mathrm{MO}_{2}(\mathrm{OH})\right]$ occurs to a certain extent in all solvents but especially in DMSO, presumably because of a stronger $\mathrm{M}-\mathrm{OH} \cdots \mathrm{OSMe}_{2}$ interaction. The DFT calculations (without consideration of $\mathrm{H}$ bonding to the $\mathrm{OH}$ group) demonstrate that the process is near thermoneutrality and show that specific H-bonding interactions with water molecules as proton donors slightly favor the process. For $\mathrm{R}=\mathrm{Me}$, formation of the methoxido derivative is clearly observed for the tungsten compound and the DFT calculations are in favor of a mononuclear formulation for the product.

The simultaneous presence of the splitting process by water and the ionic dissociation, as demonstrated in water-methanol mixtures, yields only two resonances, the position of which shifts with the water content, because of a rapid self-exchange by proton transfer between $\left[\mathrm{Cp} * \mathrm{MO}_{2}(\mathrm{OH})\right]$ and $\left[\mathrm{Cp} * \mathrm{MO}_{3}\right]^{-}$on one side, and an associative exchange between $\left[\mathrm{Cp}^{*} \mathrm{MO}_{2}(\mathrm{~S})\right]^{+}$and $\left[\mathrm{Cp}_{2}{ }_{2} \mathrm{M}_{2} \mathrm{O}_{5}\right](\mathrm{S}=$ water or methanol) on the other side. The latter occurs via rapid solvent dissociation and formation of the trinuclear $\left[\mathrm{Cp}^{*} \mathrm{M}_{3} \mathrm{O}_{7}\right]^{+}$ intermediate.

Finally, addition of base $\left(\mathrm{Et}_{3} \mathrm{~N}\right)$ converts $\left[\mathrm{Cp}^{*}{ }_{2} \mathrm{M}_{2} \mathrm{O}_{5}\right]$ to $\left[\mathrm{Cp} * \mathrm{MO}_{3}\right]^{-}$with the stoichiometric intervention of water, whereas the addition of a strong acid in the less dissociating solvents (MeCN, acetone, DMSO) does not clearly reveal conversion into the cationic form, but the aforementioned rapid exchange between the two species and the proximity of their chemical shift could mask the possible occurrence of this process. This is a point of great interest to us, because salts containing the $\left[\mathrm{Cp} * \mathrm{MO}_{2}(\mathrm{~S})\right]^{+}$cation have not yet been isolated for either metal with any neutral donor and current mechanistic hypotheses for the catalytic activity of compounds $\left[\mathrm{Cp}{ }_{2} \mathrm{M}_{2} \mathrm{O}_{5}\right]$ in olefin epoxidation have considered the involvement of such species. ${ }^{[16]}$ Efforts aimed at investigating this cationic complex, particularly in $\mathrm{MeCN}$ and particularly in terms of its catalytic activity, will therefore be pursued in our laboratory.

\section{Experimental Section}

General procedures. The electrical conductivity measurements were carried out with a YSI model 35 conductimeter and a Beckman 35 Conductivity Cell. The ${ }^{1} \mathrm{H}$ NMR spectra were recorded on a Bruker DPX 300 spectrometer. The resonances were calibrated relative to the residual solvent peak (acetone- $d_{6}, 2.064 ; \mathrm{CD}_{3} \mathrm{CN}, 1.936$; $\mathrm{CD}_{3} \mathrm{OD}, 3.329$ for the $\mathrm{CHD}_{2}$ group; DMSO- $\left.d_{6}, 2.505\right)$ and reported in ppm downfield from TMS. For the spectra recorded under extreme $\mathrm{pH}$ conditions (particularly in the presence of a large amount of strong acid) the solvent peak was assumed invariant and calibrated to the above mentioned values. For the $\mathrm{CD}_{3} \mathrm{OD} / \mathrm{D}_{2} \mathrm{O}$ mixtures, the methanol $\mathrm{CHD}_{2}$ resonance was also considered invariant with respect to the change of the $\mathrm{CD}_{3} \mathrm{OD} / \mathrm{D}_{2} \mathrm{O}$ ratio and $\mathrm{pH}$. The starting compounds, $\left[\mathrm{Cp}^{*}{ }_{2} \mathrm{Mo}_{2} \mathrm{O}_{5}\right],\left[\mathrm{Cp}_{2}{ }_{2} \mathrm{~W}_{2} \mathrm{O}_{5}\right]$ and $\mathrm{Na}\left[\mathrm{Cp} * \mathrm{WO}_{3}\right]$, were prepared as described in the literature. ${ }^{[3 \mathrm{f}]}$ The compounds trifluoroacetic acid (99\%, ACROS), triethylamine (99\%, ACROS), 15-crown-5 (98\%, Aldrich), and the deuterated solvents (acetonitrile- $d_{3}$, acetone- $d_{6}$, methanol- $d_{4}$, dmso- $d_{6}$; EURISO-TOP) were used as received.

Computational details. All DFT calculations were performed with Gaussian 09. ${ }^{[17]}$ Calculations were carried out at the DFT level of theory using the hybrid functional B3PW91 ${ }^{[18]}$ and M06. ${ }^{[19]}$ Geometry optimizations have been achieved without any symmetry restriction in solvent (acetonitrile, methanol, acetone, dimethyl sulfoxide and water) by means of the SMD solvation model. ${ }^{[20]}$ Calculations of vibrational frequencies were systematically done in order to characterize the nature of the stationary points. Stuttgart effective core potentials and their associated basis set were used for Mo and $\mathrm{W} .^{[21]}$ The basis sets were augmented by a set of polarization functions $(\zeta \mathrm{f}=1.043$ for Mo and $\zeta \mathrm{f}=0.823$ for $\mathrm{W}$ ). Hydrogen, carbon and oxygen atoms were treated with 6 $311 \mathrm{G}(\mathrm{d}, \mathrm{p})$ triple- $\zeta$ basis sets. ${ }^{[22]}$ The electron density and partial charge distribution were examined in terms of localized electron-pair bonding units by using the NBO program. ${ }^{[23]}$ The NBO program has also been used to perform natural population analyses (NPA), which afford the natural atomic charges on each atom.

\section{Acknowledgements}

We are grateful to the CNRS (Centre National de la Recherche Scientifique), to the IUF (Institut Universitaire de France) and to Celal Bayar University (project FBE 2010-081) for support of this work. This work was granted access to the HPC resources of CINES under the allocation 2010-086343 made by GENCI (Grand Equipement National de Calcul Intensif) and to the resources of the CICT (Centre Interuniversitaire de Calcul de Toulouse, project CALMIP). I. D. R. acknowledges a postdoctoral fellowship from Universitat Autònoma de Barcelona.

[1] a) W. A. Herrmann and F. E. Kühn, Acc. Chem. Res. 1997, 30, 169-180; b) C. C. Romão, F. E. Kühn and W. A. Herrmann, Chem. Rev. 1997, 97, 3197; c) F. E. Kühn, A. M. Santos and W. A. Herrmann, Dalton Trans. 2005, 2483-2491; d) C. Freund, W. Herrmann and F. E. Kühn, Topics Organometal. Chem. 2007, 22, 39-77.

[2] a) M. Abrantes, A. Santos, J. Mink, F. Kühn and C. Romão, Organometallics 2003, 22, 2112-2118; b) J. Zhao, A. M. Santos, E. Herdtweck and F. E. Kühn, J. Mol. 
Catal. A 2004, 222, 265-271; c) D. Betz, A. Raith, M. Cokoja and F. E. Kuhn, ChemSusChem 2010, 3, 559-562; d) C. Freund, M. Abrantes and F. E. Kühn, J. Organomet. Chem. 2006, 691, 3718-3729.

[3] a) E. Collange, J. Garcia and R. Poli, New J. Chem. 2002, 26, 1249-1256; b) E. Collange, L. Metteau, P. Richard and R. Poli, Polyhedron 2004, 23, 2605-2610; c) F. Demirhan, J. Gun, O. Lev, A. Modestov, R. Poli and P. Richard, J. Chem. Soc, Dalton Trans. 2002, 2109-2111; d) F. Demirhan, P. Richard and R. Poli, Inorg. Chim. Acta 2003, 347, 61-66; e) F. Demirhan, B. Çagatay, D. Demir, M. Baya, J.-C. Daran and R. Poli, Eur. J. Inorg. Chem. 2006, 757-764; f) C. Dinoi, G. Taban, P. Sözen, F. Demirhan, J.-C. Daran and R. Poli, J. Organomet. Chem. 2007, 692, 3743-3749; g) G. Taban-Çaliskan, D. Agustin, F. Demirhan, L. Vendier and R. Poli, Eur. J. Inorg. Chem. 2009, 5219-5226; h) R. Poli, Chem. Eur. J. 2004, 10, 332-341

[4] a) A. M. Martins, C. C. Romão, M. Abrantes, M. C. Azevedo, J. Cui, A. R. Dias, M T. Duarte, M. A. Lemos, T. Lourenço and R. Poli, Organometallics 2005, 24, $2582-$ 2589; b) C. Dinoi, M. Ciclosi, E. Manoury, L. Maron, L. Perrin and R. Poli, Chem. Eur. J. 2010, 16, 9572-9584.

[5] J.-E. Jee, A. Comas-Vives, C. Dinoi, G. Ujaque, R. van Eldik, A. Lledós and R. Poli, Inorg. Chem 2007, 46, 4103-4113.

[6] T. L. Broadwater and R. L. Kay, J. Solut. Chem. 1975, 4, 745-762.

[7] W. J. Geary, Coord. Chem. Rev. 1971, 7, 81-122.

[8] P. G. Sears, G. R. Lester and L. R. Dawson, J. Phys. Chem. 1956, 60, 1433-1436.

[9] K.-H. Tytko and O. Glemser, Adv. Inorg. Chem. Radiochem. 1976, 19, 239-315.

[10] a) M. B. O'Regan, M. G. Vale, J. F. Payack and R. R. Schrock, Inorg. Chem. 1992, 31, 1112-1115; b) M. S. Rau, C. M. Kretz, G. L. Geoffroy and A. L. Rheingold, Organometallics 1993, 12, 3447-3460.

[11] J. Gun, A. Modestov, O. Lev, D. Saurenz, M. A. Vorotyntsev and R. Poli, Eur. J. Inorg. Chem. 2003, 482-492.

[12] P. Sözen, J.-C. Daran, E. Manoury, F. Demirhan and R. Poli, J. Organomet. Chem 2011, 696, 2275-2279.

[13] P. Leoni, M. Pasquali, L. Salsini, C. di Bugno, D. Braga and P. Sabatino, J. Chem Soc. Dalton Trans. 1989, 155-159.

[14] C. Cappelli, B. Mennucci, C. O. da Silva and J. Tomasi, J. Chem. Phys. 2000, 112, $5382-5392$.

[15] A. V. Iogansen, Theor. Experim. Khim., 1971, 7, 302-311.

[16] a) A. Comas-Vives, A. Lledós and R. Poli, Chem. Eur. J. 2010, 16, 2147-2158; b) C. Dinoi, R. Poli, L. Perrin and L. Maron, Dalton Trans. 2012, 41, 1131-1133.
[17] M. J. Frisch, G. W. Trucks, H. B. Schlegel, G. E. Scuseria, M. A. Robb, J. R Cheeseman, G. Scalmani, V. Barone, B. Mennucci, G. A. Petersson, H. Nakatsuji, M. Caricato, X. Li, H. P. Hratchian, A. F. Izmaylov, J. Bloino, G. Zheng, J. L. Sonnenberg, M. Hada, M. Ehara, K. Toyota, R. Fukuda, J. Hasegawa, M. Ishida, T. Nakajima, Y. Honda, O. Kitao, H. Nakai, T. Vreven, J. Montgomery, J. A., J. E. Peralta, F. Ogliaro, M. Bearpark, J. J. Heyd, E. Brothers, K. N. Kudin, V. N. Staroverov, R. Kobayashi, J. Normand, K. Raghavachari, A. Rendell, J. C. Burant, S. S. Iyengar, J. Tomasi, M. Cossi, N. Rega, N. J. Millam, M. Klene, J. E. Knox, J. B. Cross, V. Bakken, C. Adamo, J. Jaramillo, R. Gomperts, R. E. Stratmann, O. Yazyev, A. J. Austin, R. Cammi, C. Pomelli, J. W. Ochterski, R. L. Martin, K. Morokuma, V. G. Zakrzewski, G. A. Voth, P. Salvador, J. J. Dannenberg, S. Dapprich, A. D. Daniels, Ö. Farkas, J. B. Foresman, J. V. Ortiz, J. Cioslowski and D. J. Fox, Gaussian 09, Revision A.01, Gaussian, Inc., Wallingford CT, 2009, p.

[18] a) J. P. Perdew in Electronic Structure of Solids, Vol. Eds.: P. Ziesche and H Eschrig), Akademie Verlag, Berlin, 1991, p. 11; b) J. P. Perdew, J. A. Chevary, S. H Vosko, K. A. Jackson, M. R. Pederson, D. J. Singh and C. Fiolhais, Physical Review B 1992, 46, 6671-6687; c) J. P. Perdew, J. A. Chevary, S. H. Vosko, K. A Jackson, M. R. Pederson, D. J. Singh and C. Fiolhais, Physical Review B 1993, 48, 4978-4978; d) J. P. Perdew, K. Burke and Y. Wang, Physical Review B 1996, 54, 16533-16539; e) G. V. J. F. Dobson, M. P. Mas in Derivation of a Generalized Gradient Approximation: the PW91 Density Functional., Vol. Plenum, New-York, 1998; f) J. P. Perdew, K. Burke and Y. Wang, Physical Review B 1998, 57, 1499914999.

[19] Y. Zhao and D. G. Truhlar, Theor. Chem. Acc. 2008, 120, 215-241.

[20] A. V. Marenich, C. J. Cramer and D. G. Truhlar, J. Phys. Chem. B 2009, 113 6378-6396.

[21] a) D. Andrae, U. Haussermann, M. Dolg, H. Stoll and H. Preuss, Theor. Chim. Acta 1990, 77, 123-141; b) J. M. L. Martin and A. Sundermann, J. Chem. Phys. $2001,114,3408-3420$.

[22] a) W. J. Hehre, R. Ditchfield and J. A. Pople, J. Chem. Phys. 1972, 56, 2257-2261; b) P. Harihara and J. Pople, Theor. Chim. Acta 1973, 28, 213-222.

[23] A. E. Reed, L. A. Curtiss and F. Weinhold, Chem. Rev. 1988, 88, 899-926.

Received: ((will be filled in by the editorial staff))

Revised: ((will be filled in by the editorial staff)) Published online: ((will be filled in by the editorial staff))

\section{Entry for the Table of Contents}

\section{Solutions of $\left[\mathrm{Cp}_{2}{ }_{2} \mathrm{M}_{2} \mathrm{O}_{5}\right]$}

Pelin Sözen-Aktaş, Iker Del Rosal, Eric Manoury, Funda Demirhan, Agustí Lledós, * and Rinaldo Poli* Page - Page

\section{Speciation of $\left[\mathrm{Cp}^{*}{ }_{2} \mathrm{M}_{2} \mathrm{O}_{5}\right](\mathrm{M}=$ $\mathrm{Mo}, \mathrm{W})$ in polar and donor solvents}
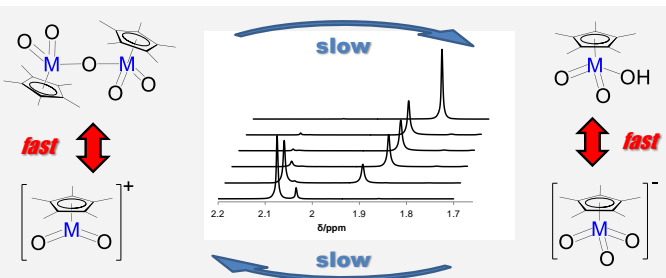

Compounds $\left[\mathrm{Cp}_{2}{ }_{2} \mathrm{M}_{2} \mathrm{O}_{5}\right]\left(\mathrm{M}=\mathrm{Mo}, \quad\left[\mathrm{Cp} * \mathrm{MO}_{2} \text { (solv) }\right]^{+}, \quad\left[\mathrm{Cp}^{*} \mathrm{MO}_{2}(\mathrm{OR})\right]\right.$ $\mathrm{W})$ reveal a rich and complex $(\mathrm{R}=\mathrm{H}, \mathrm{Me})$ and $\left[\mathrm{Cp}^{*} \mathrm{MO}_{3}\right]^{-}$ speciation chemistry in polar protic depending on the solvent nature and and aprotic solvents, yielding on the amount of water present. various species including 